\title{
Chemical composition of modern and fossil Hippopotamid teeth and implications for paleoenvironmental reconstructions and enamel formation - Part 1: Major and minor element variation
}

\author{
G. Brügmann ${ }^{1}$, J. Krause ${ }^{2,3}$, T. C. Brachert ${ }^{4}$, O. Kullmer ${ }^{5}$, F. Schrenk ${ }^{5}$, I. Ssemmanda ${ }^{6}$, and D. F. Mertz ${ }^{1}$ \\ ${ }^{1}$ Institut für Geowissenschaften, Joh.-Joachim-Becher-Weg 21, Universität Mainz, 55099 Mainz, Germany \\ ${ }^{2}$ Max-Planck-Institut fr Chemie, Joh.-Joachim-Becher-Weg 27, 55128 Mainz, Germany \\ ${ }^{3}$ Institut für Mineralogie, Corrensstraße 24, Universität Münster, 48149 Münster, Germany \\ ${ }^{4}$ Institut für Geophysik und Geologie, Talstraße 35, Universität Leipzig, 4103 Leipzig, Germany \\ ${ }^{5}$ Forschungsinstitut und Naturmuseum Senckenberg, Senckenberganlage 25, 60325 Frankfurt, Germany \\ ${ }^{6}$ Geology Department, Makerere University, 7062, Uganda
}

Correspondence to: G. Brügmann (bruegmag@uni-mainz.de)

Received: 11 April 2011 - Published in Biogeosciences Discuss.: 31 May 2011

Revised: 18 November 2011 - Accepted: 28 November 2011 - Published: 6 January 2012

\begin{abstract}
Bioapatite in mammalian teeth is readily preserved in continental sediments and represents a very important archive for reconstructions of environment and climate evolution. This project provides a comprehensive data base of major, minor and trace element and isotope tracers for tooth apatite using a variety of microanalytical techniques. The aim is to identify specific sedimentary environments and to improve our understanding on the interaction between internal metabolic processes during tooth formation and external nutritional control and secondary alteration effects. Here, we use the electron microprobe to determine the major and minor element contents of fossil and modern molar enamel, cement and dentin from Hippopotamids. Most of the studied specimens are from different ecosystems in Eastern Africa, representing modern and fossil lacustrine (Lake Kikorongo, Lake Albert, and Lake Malawi) and modern fluvial environments of the Nile River system.

Secondary alteration effects - in particular $\mathrm{FeO}, \mathrm{MnO}, \mathrm{SO}_{3}$ and $\mathrm{F}$ concentrations - are 2 to 10 times higher in fossil than in modern enamel; the secondary enrichment of these components in fossil dentin and cement is even higher. In modern and fossil enamel, along sections perpendicular to the enamel-dentin junction (EDJ) or along cervix-apex profiles, $\mathrm{P}_{2} \mathrm{O}_{5}$ and $\mathrm{CaO}$ contents and the $\mathrm{CaO} / \mathrm{P}_{2} \mathrm{O}_{5}$ ratios are very constant ( $\operatorname{StdDev} \sim 1 \%$ ). Linear regression analysis reveals tight control of the $\mathrm{MgO}\left(R^{2} \sim 0.6\right), \mathrm{Na}_{2} \mathrm{O}$ and $\mathrm{Cl}$ variation (for both $R^{2}>0.84$ ) along EDJ-outer enamel rim profiles,
\end{abstract}

despite large concentration variations (40\% to $300 \%$ ) across the enamel. These minor elements show well defined distribution patterns in enamel, similar in all specimens regardless of their age and origin, as the concentration of $\mathrm{MgO}$ and $\mathrm{Na}_{2} \mathrm{O}$ decrease from the enamel-dentin junction (EDJ) towards the outer rim, whereas $\mathrm{Cl}$ displays the opposite trend.

Fossil enamel from Hippopotamids which lived in the saline Lake Kikorongo have a much higher $\mathrm{MgO} / \mathrm{Na}_{2} \mathrm{O}$ ratio $(\sim 1.11)$ than those from the Neogene fossils of Lake Albert $\left(\mathrm{MgO} / \mathrm{Na}_{2} \mathrm{O} \sim 0.4\right)$, which was a large fresh water lake like those in the western Branch of the East African Rift System today. Similarly, the $\mathrm{MgO} / \mathrm{Na}_{2} \mathrm{O}$ ratio in modern enamel from the White Nile River $(\sim 0.36)$, which has a Precambrian catchment of dominantly granites and gneisses and passes through several saline zones, is higher than that from the Blue Nile River, whose catchment is the Neogene volcanic Ethiopian Highland $\left(\mathrm{MgO} / \mathrm{Na}_{2} \mathrm{O} \sim 0.22\right)$. Thus, particularly $\mathrm{MgO} / \mathrm{Na}_{2} \mathrm{O}$ might be a sensitive fingerprint for environments where river and lake water have suffered strong evaporation.

Enamel formation in mammals takes place at successive mineralization fronts within a confined chamber where ion and molecule transport is controlled by the surrounding enamel organ. During the secretion and maturation phases the epithelium generates different fluid composition, which in principle, should determine the final composition of enamel apatite. This is supported by co-linear relationships between $\mathrm{MgO}, \mathrm{Cl}$ and $\mathrm{Na}_{2} \mathrm{O}$ which can be interpreted 
as binary mixing lines. However, if maturation starts after secretion is completed, the observed element distribution can only be explained by equilibration of existing and addition of new apatite during maturation. It appears the initial enamel crystallites precipitating during secretion and the newly formed bioapatite crystals during maturation equilibrate with a continuously evolving fluid. During crystallization of bioapatite the enamel fluid becomes continuously depleted in $\mathrm{MgO}$ and $\mathrm{Na}_{2} \mathrm{O}$, but enriched in $\mathrm{Cl}$ which results in the formation of $\mathrm{MgO}$, and $\mathrm{Na}_{2} \mathrm{O}$-rich, but Cl-poor bioapatite near the EDJ and $\mathrm{MgO}-$ and $\mathrm{Na}_{2} \mathrm{O}$-poor, but $\mathrm{Cl}$-rich bioapatite at the outer enamel rim.

The linkage between lake and river water compositions, bioavailability of elements for plants, animal nutrition and tooth formation is complex and multifaceted. The quality and limits of the $\mathrm{MgO} / \mathrm{Na}_{2} \mathrm{O}$ and other proxies have to be established with systematic investigations relating chemical distribution patterns to sedimentary environment and to growth structures developing as secretion and maturation proceed during tooth formation.

\section{Introduction}

Apatite $\left(\mathrm{Ca}_{5}\left(\mathrm{PO}_{4}\right)_{3}(\mathrm{~F}, \mathrm{Cl}, \mathrm{OH})\right)$ is the most common phosphate mineral, and is widely distributed in igneous, sedimentary and metamorphic rocks. It plays a key part of the terrestrial phosphorus cycle and on a geological time scale apatite regulates the supply of biomineralizing phosphorus in the biosphere. Phosphorus is essential for the synthesis of soft tissue, but it is also a vital component of bones and teeth, which are intricate frameworks of proteins and apatite. The nano- to microcrystalline structure of tooth bioapatite has several sites for cations and anions which permits the uptake of a variety of elements with rather different chemical features. Chemical elements find their way from the geosphere and biosphere into plant and animal tissue, including bone and tooth material. For this reason, the chemical and isotopic composition of bioapatite became an important complementary and even stand-alone tool to monitor climatic and ecological change (Sillen, 1988; MacFadden et al., 1999; Kohn and Cerling, 2002; Koch, 2007; Tütken et al., 2008).

Despite a common mineralogy, bone, cement, dentin and enamel in mammals have different microstructures and chemical compositions. Compared to cementum, dentin and bone, tooth enamel has a high mineral content of ca. $96 \%$ compared to ca. $70 \%$ in dentin. Enamel also consists of highly ordered microcrystals compared to nm-sized crystallites in cementum, dentin and bone (Glimcher et al., 1990; Glimcher, 2006; Pasteris et al., 2008). In effect, enamel has significantly less pore spaces and a smaller surface to volume ratio which minimize the introduction of diagenetic solutions, adsorption of metals and recrystallization, whereas dentin, cementum and bone is chemically less stable. Thus, enamel is regarded as one of the most diagenetically in- ert biominerals and its chemical and isotopic compositions are preferred paleoenvironmental and paleoclimatic proxies (Kohn, 1996; Fricke and O’Neil, 1996; Fricke et al., 1998; Koch, 1998; Kohn and Cerling, 2002; Koch et al., 2004; Forbes et al., 2010) providing information on diet, migration patterns and habitat use even on a seasonal scale (Kohn et al., 1996; Koch, 1998; Sponheimer et al., 2003; Cerling et al., 2003, 2008; Boisserie et al., 2005). During precipitation, biominerals not only respond to the local chemical environment, i.e. the bioavailability of chemical elements, but also to physiological, taxonomical characteristics.

Patterns of major and minor element compositions in teeth of mammals have been systematically studied in the seventies and early eighties of the last century with regard to tooth development and mineralization and tooth diseases using electron microprobe and more recently secondary ion mass spectrometry (SIMS) (Johnson, 1972; Shaw and Yen, 1972; Norén et al., 1983; Verbeeck et al., 1985; Driessens et al., 1990; Lundgren et al., 1998). Trace element studies concentrated on $\mathrm{Sr}, \mathrm{Ba}, \mathrm{Zn}$ and $\mathrm{Pb}$ contents and $\mathrm{Sr} / \mathrm{Ca}$, $\mathrm{Ba} / \mathrm{Ca}$ and $\mathrm{Zn} / \mathrm{Ca}$ ratios have been used to distinguish dietary groups or trophic levels of mammals and to discriminate between geological background and vegetation type (Sillen and Kavanagh, 1982; Safont et al., 1998; Sponheimer and LeeThorp, 2006; Dolphin and Goodman, 2009). However, there is no systematic data base for testing the potential of major, minor and trace elements as tracers of environmental change.

Oxygen and carbon stable isotope systems represent the most valuable climate proxies for terrestrial environments (Kohn and Cerling, 2002; Boisserie, 2005; Cerling et al., 2008). $\delta^{18} \mathrm{O}$ and $\delta^{13} \mathrm{C}$ of mammalian tooth enamel are well established tools for reconstructing herbivore diet (C3 vs. C4) and drinking water composition (i.e. meteoric water) in the fossil record (Longinelli, 1984; Sillen, 1988; Cerling et al., 1997; Koch et al., 2004; Tütken et al., 2008). Similarly, radiogenic isotope compositions of $\mathrm{Sr}, \mathrm{Nd}$ or $\mathrm{Pb}$ of animal tissue are markers of the provenance or tracers for migration and diet changes (Simonetti et al., 2008; Copeland et al., 2010; Fitch et al., 2010; Tütken et al., 2011).

During the fossilization process bone and tooth materials become chemically and physically altered as chemical components diffuse into the bioapatite and become adsorbed on the crystal surfaces or cause recrystallization of the apatite (Millard and Hedges, 1996; Kohn, 2008). Whether the original animal tissue has been altered or not represents an important and disputed issue in many geochemical studies (Kohn et al., 1999; Dauphin and Williams, 2004; Sponheimer and Lee-Thorp, 2006). However, mobilization of an element within the sediment column and eventually its incorporation into the apatite tissue is controlled by environmental and climatic conditions set apart by temperature, redox conditions, $\mathrm{pH}$, and presence of complexing ligands. Therefore, the trace element distribution imposed on apatite tissue during diagenesis can potentially also been used as a proxy for certain environments and climates (Wright et al., 1987; Patrick et al., 
2004; Trueman et al., 2006; Anderson et al., 2007; Grandstaff and Terry Jr., 2009). Yet, this approach has to be tested thoroughly because chemical components can be exchanged with the sedimentary environment on time scales of millions or even tens of millions years as suggested by recent studies on bones (Herwartz et al., 2011).

Most of the studies summarized above used a bulk sample approach in order to determine the chemical and isotopic compositions. Given that this technique takes a large sample volume information is not provided on the spatial-temporal progress of chemical change either during the growth phase of the tooth or during the interaction of the burial environment with the tooth. Such a resolution, however, is essential in order to identify and understand the development of the individual fingerprint of these processes and before detailed paleoecological reconstructions can be made.

This study is part of a comprehensive project which systematically investigates the distribution of major, minor and trace elements as well as stable $\left(\delta^{18} \mathrm{O}\right.$ and $\left.\delta^{13} \mathrm{C}\right)$ and radiogenic $(\mathrm{Sr}, \mathrm{Pb})$ isotopic compositions in modern and fossil Hippopotamid teeth using analytical techniques which provide high spatial resolution, such as the electron microprobe, scanning electron microscope and LA-ICPMS. These techniques can minimize invasion or destruction of fossils and achieve maximum spatial resolution. The present study provides a detailed data base on the composition of tooth apatite in order to identify distinct environments by evaluating the interaction between internal processes during tooth formation, external nutritional controls and diagenetic alteration. We compare tooth material of Hippopotamids from different environments in Eastern Africa, representing modern and fossil lacustrine, and modern fluvial environments. We show that the minor element distribution is established during the maturation process of amelogenesis and the patterns of $\mathrm{MgO}$ variation to be a tool for distinguishing fluvial, saline and fresh water lake environments. Trace element and radiogenic isotope variations in the same samples will be presented in a second paper. Stable isotope data have already been published (Brachert et al., 2010) and will be integrated into the results of the major, trace element and radiogenic isotope studies.

\section{Samples and methods}

\subsection{Samples}

Hippopotamids are regarded to be opportunistic grazers. Due to their water-dependency they live within a small territory, which commonly is confined to 2 to $5 \mathrm{~km}$ of the water body (Chansa et al., 2011). Samples for chemical analyses of tooth enamel, dentin and cementum were selected from an extensive collection of recent and fossil Hippopotamids available to us at the Museum of Natural History (Kampala, Uganda), Institut für Geowissenschaften (Mainz,
Germany), Forschungsinstitut Senckenberg (Frankfurt, Germany), and Naturhistorisches Museum Wien (Vienna, Austria). We study molars (M3, premolar, molar fragments) of Hippopotamids, since these are common fossils of mammals in terrestrial sediments and these robust structures are usually well preserved. In addition, geochemical data in molars are not biased by potential effects of nursing in deciduous teeth. One modern tooth is derived from a zoo collection now housed at the Institut für Geowissenschaften, University of Mainz, Germany (sample S276). Further samples of recent teeth are from animals living in natural environments, including the freshwater lakes of Lake Malawi (Senga Bay, sample Mal-08), and Lake Albert (near the village of Sebugoro in Uganda, sample Alb-10) and the river Nile. The samples from the river Nile represent mini cores of enamel taken at the "Naturhistorisches Museum Wien" in Vienna. Details of the coring procedure are given by Brachert et al. (2010). The animals lived in the Sudanese part of the Upper Nile (samples Nile-1, -2), the White Nile (sample Nile-3) and in the Blue Nile (sample Nile-4). The fossil molar teeth studied are from different environments in Eastern Africa, representing fossil lacustrine and fluvial environments, vary in age (recent to 6.5 Ma) and in degree of preservation (Brachert et al., 2010). Sample "Kikorongo" was collected from sediments of the Kikorongo Crater to the SE of the Rwenzori Mountains. The crater belongs to the Katwe-Kikorongo volcanic field and is believed to be $0.01 \mathrm{Ma}$ old. Today, this crater is filled with alkaline, saline water which probably represents a mixture of geothermal and evaporated lake water (Bahati et al., 2005). The remaining 14 fossil specimens were collected in Neogene sediments of the Nkondo-Kaiso and Makondo area at the East shore of Lake Albert (Brachert et al., 2010). Lake Albert is one of a series of large freshwater lakes in the western branch of the East African Rift (Lake Edward, Lake Kivu, Lake Tanganyika, Lake Rukwa, and Lake Malawi) which is a graben system dominantly filled with fluvio-deltaic deposits and lake sediments. The lithostratigraphy as well as the tectonic and paleoecological evolution of Lake Albert is well established (Pickford et al., 1993; Senut and Pickford, 1994; Beuning et al., 1997; Van Damme and Pickford, 2003). Information related to our samples, including the age model, is summarized by Brachert et al. (2010). Taxonomically, all modern teeth studied belong to the species Hippopotamus amphibius. However, some of the fossil teeth collected in Uganda are conspicuous for their small size. It has been suggested to classify these using open taxonomy as "Small Hippopotamids" before more detailed systematic analyses have been carried out (Boisserie, 2005).

\subsection{Microprobe analysis}

Carbon-coated polished halves of drill cores and parasagittal or frontal thin sections up to $300 \mu \mathrm{m}$ thick were used for the microprobe measurements. The samples were analysed for major and minor elements using the Jeol 
JXA8200 microprobe at the Max-Planck-Institute for Chemistry, Mainz. We used natural minerals and oxides for calibration. Instrument drift during the analysis was corrected, if necessary with repeated measurements of standard apatite (USNM 104021). Table S1 in the Supplement summarizes the measurement conditions, the achieved detection limits and representative standard errors. The spot analyses were done with an acceleration voltage of $15 \mathrm{kV}$, a probe current of $12 \mathrm{nA}$ and a defocussed beam with a diameter of $20 \mu \mathrm{m}$ in order to account for the limited stability of enamel and dentin under the electron beam. Counting times were $20-60$ s on the peak and $10-40 \mathrm{~s}$ on the background. Distribution maps for major elements were measured with a dwell time of $110 \mathrm{~ms}$ at a beam current of $25 \mathrm{nA}$ at $15 \mathrm{kV}$ with a beam diameter between 1 and $20 \mu \mathrm{m}$. Strontium, Cl, F, Ca, and P were detected with WDS spectrometers and $\mathrm{Fe}, \mathrm{Mg}$ and $\mathrm{Si}$ with an EDS spectrometer. The step size varied between 1 and $40 \mu \mathrm{m}$.

The major element composition of 20 to 30 spots was systematically determined along $2-3 \mathrm{~mm}$ long profiles approximately perpendicular to the enamel-dentin junction (EDJ). In most cases these profiles started at the outside margin of the tooth which is directly exposed to local weathering and leaching, and chemical and/or isotopic interactions with soils, sediments or pore water. The outer part of the tooth crown consists either of cement or enamel. The profiles continue crossing the EDJ and ending with a few spot analyses in dentin (Fig. 1). If possible, two profiles were sampled near the apex and cervix, respectively, to cover the full spectrum of compositional variability. In a few specimens profiles were measured from the cervix to the apex, close to and parallel to the EDJ (S276-L, Mal-08-L, 5306-L).

\section{Results: major and minor element composition of Hippopotamid molar teeth}

Tables 1, 2, and 3 summarize the composition of enamel, dentin and cement from the modern specimens and of fossil teeth from Lake Kikorongo and Lake Albert. The complete set of 1880 major element analyses on 26 teeth specimens is presented in the electronic attachment (Tables S2S4). One concern when analyzing different tooth materials, with relative large spot sizes is their variable porosity which pretends different apatite compositions. The total oxide sum in the various segments of the teeth is always considerably less than $100 \mathrm{wt}$. \% ranging from about $93 \mathrm{wt}$. \% for enamel to $70 \mathrm{wt} . \%$ for dentin and cement (total in Tables 1, 2, 3). The deviation from $100 \%$ is mainly due to the presence of carbonate and residual organic substances - which have not been determined - and of empty pore spaces within the measured spot area. This also becomes obvious in element maps like those of $\mathrm{Ca}$ shown in Fig. 2. It suggests a large concentration difference between dentin, cement and enamel although effectively the difference is just about $3 \mathrm{wt} . \% \mathrm{CaO}$. The $\mathrm{Ca}$ distribution also indicates an intensity decrease from
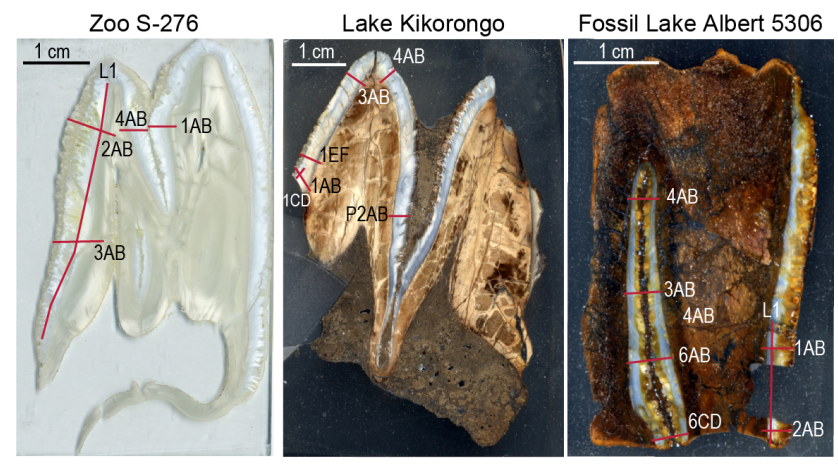

Fig. 1. Thin sections of selected samples of molar Hippopotamid teeth ranging in age from recent (S276, molar M3), $10 \mathrm{ka}$ (Lake Kikorongo, molar M3) to $2.3 \mathrm{Ma}$ (5306, molar frag.) indicate variable degrees of diagenetic overprint. Profiles of major and minor element analyses are indicated.

the apex towards the cervix (Fig. 2). These variations do not only indicate systematic differences in the $\mathrm{Ca}$ content of bioapatite, but also reflect differences in mineral density between enamel and dentin ( $\sim 95$ wt. \% versus 70 wt. \%, respectively; Pasteris et al., 2008) and within enamel, which is characteristic of mammal enamel in general (Weatherell et al., 1974; Robinson et al., 1995). In order to facilitate compositional comparison between different tooth materials, the data shown in Tables 1 to 3 and in the Figs. 3, 4, and 8 are normalized to $100 \%$. The original analytical results are given in the electronic attachment. In our sample set the discussion of concentrations or element ratios using $\mathrm{CaO}$ or $\mathrm{P}_{2} \mathrm{O}_{5}$ as the denominator are interchangeable and provide equivalent interpretations and conclusions regarding chemical variations induced by metabolic/nutritional and diagenetic processes.

The concentrations of the main oxides $\mathrm{CaO}$ and $\mathrm{P}_{2} \mathrm{O}_{5}$ in modern and fossil enamel vary by about $1 \%$ (1 standard deviation; Table 1), although dentin and cement show larger concentration variations of up to $7.6 \%$ (Tables 2,3 ). Typically, fossil dentin and cement are more heterogeneous and have higher $\mathrm{CaO}$ and lower $\mathrm{P}_{2} \mathrm{O}_{5}$ contents than their modern counterparts (Fig. 3). In fossil samples dentin and cement have lower $\mathrm{CaO}$ and $\mathrm{P}_{2} \mathrm{O}_{5}$ contents than enamel (Fig. 3). Modern and fossil enamel have on average similar $\mathrm{CaO}$ and $\mathrm{P}_{2} \mathrm{O}_{5}$ contents. This is also reflected in the similar $\mathrm{CaO} / \mathrm{P}_{2} \mathrm{O}_{5}$ ratio of modern and fossil enamel (1.28 \pm 0.3 versus $1.31 \pm 0.2$, respectively; Table 1). Modern dentin and cement have lower and higher whereas fossil dentin and cement have always higher $\mathrm{CaO} / \mathrm{P}_{2} \mathrm{O}_{5}$ ratios than enamel (Tables 2, 3). Figure 4 summarizes typical distribution patterns along profiles from the outside rim, across the EDJ into the dentin. Enamel thickness has been normalized to 1 in order to minimize the influence of variable enamel thickness in different specimens. The concentration patterns of $\mathrm{CaO}$ and $\mathrm{P}_{2} \mathrm{O}_{5}$ across the enamel are flat and similar for all specimens, reflecting the small standard deviation of the average concentrations. 

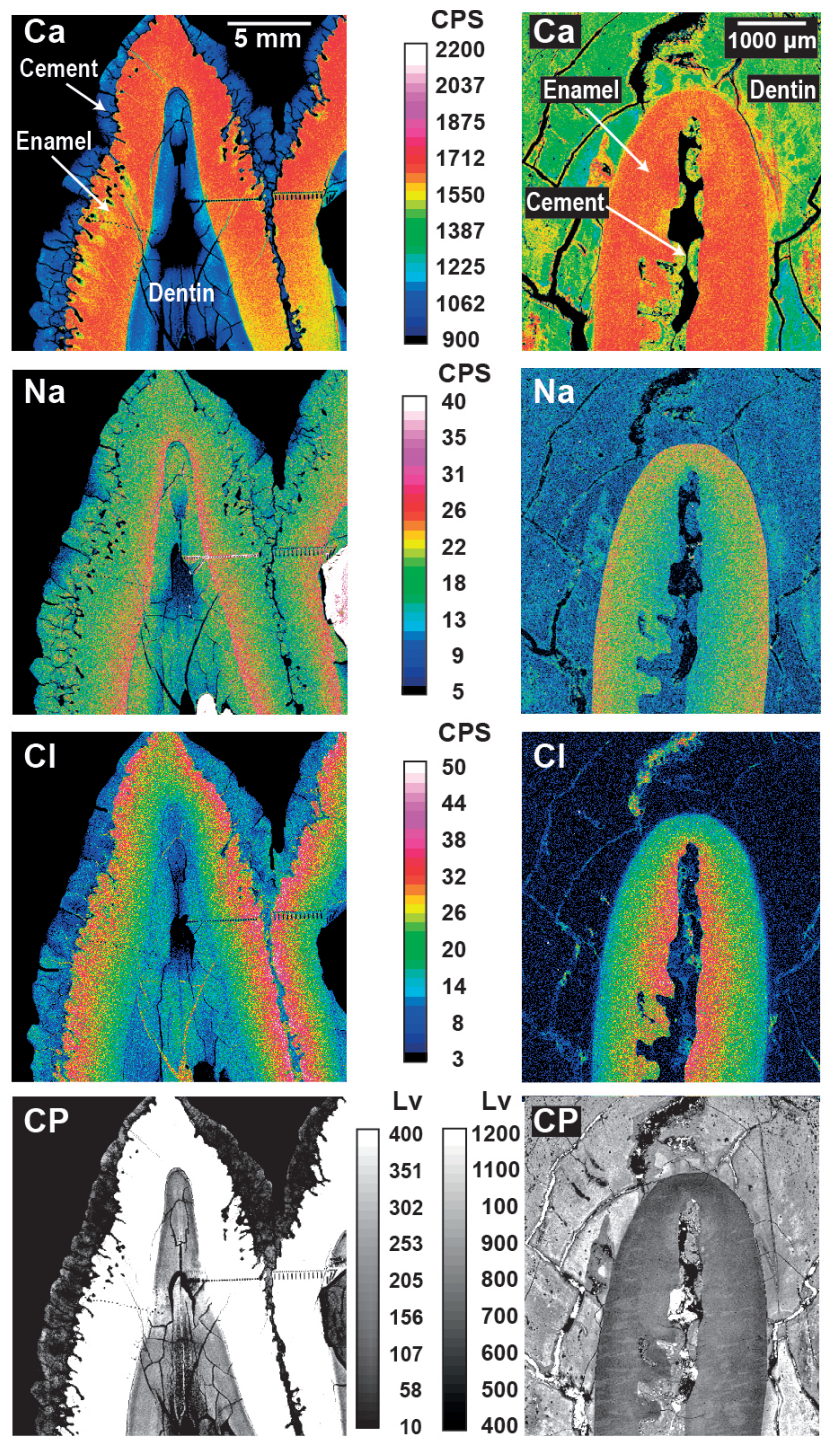

Fig. 2. Element maps for $\mathrm{Ca}, \mathrm{Na}, \mathrm{Cl}$ and backscattered images (CP) of modern (sample S276, molar M3; left row) and fossil (sample 5306, molar frag.; right row) Hippopotamid teeth. Note the significantly higher $\mathrm{Ca}$ intensities in enamel compared to that in dentin and cement, which reflects lower porosity and higher $\mathrm{Ca}$ concentrations in enamel. Variation of $\mathrm{Ca}$ along an apex-cervix profile reflects differences in mineral density. The zonal distribution of $\mathrm{Cl}$ and $\mathrm{Na}$ in enamel reflects concentration variation. Note the contrasting brightness levels (CP) in modern and fossil enamel and dentin. Modern dentin has a low average atomic number (low $Z$ ) compared to enamel. Intensities are reversed in fossil materials.

The $\mathrm{P}_{2} \mathrm{O}_{5}$ contents in dentin and cement are systematically lower, but the $\mathrm{CaO}$ can be enriched or depleted relatively to the enamel (Fig. 4).

The third most abundant component in modern teeth is $\mathrm{Na}_{2} \mathrm{O}(\sim 1 \mathrm{wt} . \%)$. Modern tooth materials and fossil enamel have similar concentrations, whereas fossil dentin and cement are on average lower in $\mathrm{Na}_{2} \mathrm{O}$ (Tables 1-3,

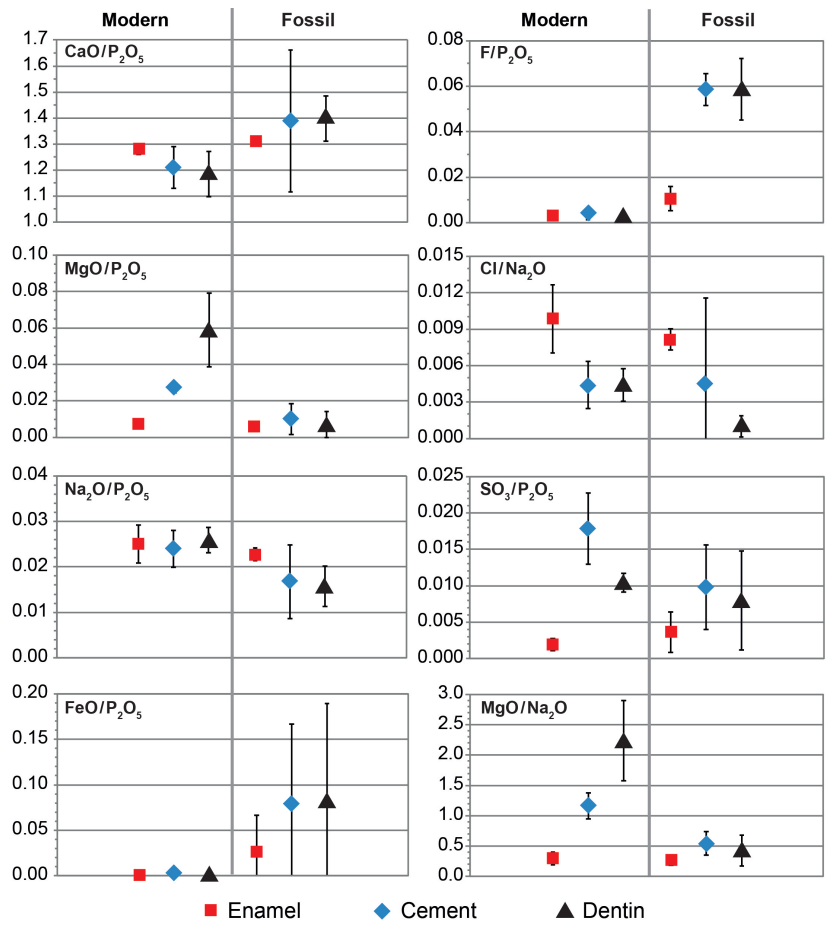

Fig. 3. Comparison of the average chemical compositions of all modern and fossil molar tooth materials from Hippopotamids.

Fig. 3). In element maps, the contacts of cement/enamel and enamel/dentin are clearly delineated by sharp concentration changes (Figs. 2, 4). Even within the enamel $\mathrm{Na}_{2} \mathrm{O}$ contents increase by about $40 \%$ from the outside towards the EDJ (Fig. 2). This is observed in all profiles perpendicular to the EDJ throughout the tooth crown, regardless of provenance and geological age of the specimen and is not due to changes in mineral density but reflects variable apatite composition. Similar $\mathrm{Na}_{2} \mathrm{O}$ distributions in enamel have been observed in other mammal teeth, for example from rats, porcupine and humans (Norén et al., 1983; Driessens et al., 1990).

The distribution pattern of $\mathrm{MgO}$ in modern and fossil Hippopotamid enamel is similar to that of $\mathrm{Na}_{2} \mathrm{O}$, as $\mathrm{MgO}$ concentrations increase from the enamel rim towards the EDJ, although the enrichment is slightly less ( $35 \%$; Figs. 2, 4). However, it differs in that modern enamel has 4 to 8 times lower concentrations than cement and dentin (Tables 1, 2, 3, Fig. 3). This pattern of $\mathrm{MgO}$ distribution between different materials is also typical for many other mammal teeth (Driessens et al., 1990; Steinfort et al., 1991). Fossil enamel from Lake Albert has $\mathrm{MgO}$ contents of about 0.22 which is within the range of the $\mathrm{MgO}$ contents in modern enamel (Fig. 3). There are two obvious exceptions; enamel of the hippopotamus tooth from Lake Kikorongo and enamel from the White Nile River have distinctively higher $\mathrm{MgO}$ contents $\left(\sim 0.4\right.$ wt. \%), and higher $\mathrm{MgO} / \mathrm{P}_{2} \mathrm{O}_{5}(>0.07)$ and $\mathrm{MgO} / \mathrm{Na}_{2} \mathrm{O}$ ratios $(>0.28)$ than all the remaining enamel samples (Table 1). 
Table 1. Average chemical composition of enamel from modern and fossil hippopotamid molar teeth.

\begin{tabular}{|c|c|c|c|c|c|c|c|c|c|c|c|c|c|c|c|c|}
\hline \multirow{3}{*}{$\begin{array}{l}\text { Enamel } \\
\text { Specimen/ Analyses }\end{array}$} & \multicolumn{2}{|c|}{ Lake Albert Modern } & \multicolumn{2}{|c|}{ Lake Malawi Modern } & \multicolumn{2}{|c|}{ Zoo S-276 Modern } & \multicolumn{2}{|c|}{ Nile Blue Modern } & \multicolumn{2}{|c|}{ Nile White Modern } & \multicolumn{2}{|c|}{ Nile Upper Modern } & \multicolumn{2}{|c|}{ Lake Kikorongo Fossil } & \multicolumn{2}{|c|}{ Lake Albert Fossil } \\
\hline & \multicolumn{2}{|c|}{$1 / 120$} & \multicolumn{2}{|c|}{$1 / 106$} & \multicolumn{2}{|c|}{$1 / 162$} & \multicolumn{2}{|c|}{$1 / 24$} & \multicolumn{2}{|c|}{$1 / 29$} & \multicolumn{2}{|c|}{$1 / 50$} & \multicolumn{2}{|c|}{$1 / 156$} & \multicolumn{2}{|c|}{$14 / 759$} \\
\hline & Ave & $1 \sigma$ & Ave & $1 \sigma$ & Ave & $1 \sigma$ & Ave & $1 \sigma$ & Ave & $1 \sigma$ & Ave & $1 \sigma$ & Ave & $1 \sigma$ & Ave & $1 \sigma$ \\
\hline $\mathrm{P}_{2} \mathrm{O}_{5}$ & 42.81 & 0.57 & 40.96 & 0.53 & 42.06 & 0.31 & 42.57 & 0.28 & 42.35 & 0.29 & 42.57 & 0.36 & 41.30 & 0.41 & 41.38 & 0.27 \\
\hline $\mathrm{SiO}_{2}$ & $<0.04$ & - & 0.56 & 0.74 & 0.14 & 0.14 & 0.07 & 0.00 & 0.05 & 0.01 & 0.05 & 0.00 & 0.10 & 0.12 & 0.13 & 0.08 \\
\hline $\mathrm{FeO}$ & 0.06 & 0.02 & 0.06 & 0.05 & 0.07 & 0.01 & 0.06 & 0.01 & 0.05 & 0.01 & 0.05 & 0.02 & 0.08 & 0.30 & 0.66 & 0.17 \\
\hline $\mathrm{CaO}$ & 53.38 & 0.65 & 54.69 & 0.45 & 54.31 & 0.36 & 53.90 & 0.25 & 53.89 & 0.28 & 54.03 & 0.35 & 54.40 & 0.44 & 54.16 & 0.35 \\
\hline $\mathrm{MgO}$ & 0.46 & 0.07 & 0.49 & 0.31 & 0.35 & 0.12 & 0.27 & 0.04 & 0.43 & 0.05 & 0.25 & 0.05 & 0.43 & 0.05 & 0.22 & 0.03 \\
\hline $\mathrm{MnO}$ & $<0.05$ & - & $<0.05$ & - & 0.08 & - & $<0.05$ & - & $<0.06$ & - & $<0.07$ & - & 0.10 & 0.11 & 0.26 & 0.11 \\
\hline $\mathrm{SrO}$ & 0.08 & 0.02 & 0.08 & 0.02 & 0.07 & 0.01 & 0.08 & 0.02 & 0.08 & 0.02 & 0.07 & 0.01 & 0.34 & 0.03 & 0.08 & 0.01 \\
\hline $\mathrm{Na}_{2} \mathrm{O}$ & 1.16 & 0.20 & 1.19 & 0.16 & 1.01 & 0.14 & 1.09 & 0.19 & 1.18 & 0.18 & 1.03 & 0.18 & 1.04 & 0.18 & 0.94 & 0.06 \\
\hline $\mathrm{F}$ & 0.16 & 0.03 & 0.23 & 0.04 & 0.14 & - & $<0.06$ & - & $<0.06$ & - & $<0.06$ & - & 0.26 & 0.21 & 0.40 & 0.18 \\
\hline $\mathrm{Cl}$ & 0.31 & 0.10 & 0.34 & 0.12 & 0.40 & 0.11 & 0.46 & 0.13 & 0.40 & 0.13 & 0.43 & 0.11 & 0.34 & 0.13 & 0.35 & 0.03 \\
\hline $\mathrm{SO}_{3}$ & 0.06 & 0.01 & 0.10 & 0.07 & 0.09 & 0.04 & 0.06 & 0.01 & 0.06 & 0.01 & 0.05 & 0.01 & 0.09 & 0.08 & 0.17 & 0.09 \\
\hline $\mathrm{K}_{2} \mathrm{O}$ & 0.04 & 0.01 & 0.03 & 0.01 & 0.03 & 0.01 & 0.05 & 0.01 & 0.05 & 0.03 & 0.05 & 0.01 & 0.04 & 0.01 & 0.04 & 0.00 \\
\hline $\mathrm{Al}_{2} \mathrm{O}_{3}$ & 0.04 & 0.00 & 0.04 & 0.01 & 0.09 & 0.10 & 0.18 & - & 0.05 & 0.02 & 0.05 & - & 0.34 & 0.10 & 0.07 & 0.03 \\
\hline $\mathrm{H}_{2} \mathrm{O}$ & 1.59 & 0.03 & 1.54 & 0.03 & 1.63 & 0.03 & 1.62 & 0.03 & 1.63 & 0.03 & 1.62 & 0.03 & 1.52 & 0.12 & 1.41 & 0.21 \\
\hline Total & 92.89 & 1.13 & 91.49 & 2.79 & 92.53 & 1.61 & 93.30 & 0.93 & 93.21 & 0.89 & 93.10 & 0.98 & 92.01 & 1.13 & 92.18 & 1.06 \\
\hline $\mathrm{CaO} / \mathrm{P}_{2} \mathrm{O}_{5}$ & 1.25 & 0.03 & 1.33 & 0.02 & 1.29 & 0.02 & 1.27 & 0.01 & 1.27 & 0.01 & 1.27 & 0.02 & 1.32 & 0.02 & 1.31 & 0.02 \\
\hline $\mathrm{MgO} / \mathrm{P}_{2} \mathrm{O}_{5}$ & 0.0108 & 0.0016 & 0.0111 & 0.0027 & 0.0083 & 0.0028 & 0.0062 & 0.0009 & 0.0101 & 0.0013 & 0.0058 & 0.0012 & 0.0105 & 0.0011 & 0.0053 & 0.0007 \\
\hline $\mathrm{FeO} / \mathrm{P}_{2} \mathrm{O}_{5}$ & 0.0013 & 0.0004 & 0.0015 & 0.0013 & 0.0018 & 0.0003 & - & - & 0.0013 & 0.0002 & 0.0012 & 0.0004 & 0.0017 & 0.0282 & 0.0288 & 0.0417 \\
\hline $\mathrm{Na}_{2} \mathrm{O} / \mathrm{P}_{2} \mathrm{O}_{5}$ & 0.0271 & 0.0047 & 0.0288 & 0.0041 & 0.0241 & 0.0035 & 0.0257 & 0.0045 & 0.0278 & 0.0042 & 0.0243 & 0.0042 & 0.0251 & 0.0046 & 0.0226 & 0.0013 \\
\hline $\mathrm{F} / \mathrm{P}_{2} \mathrm{O}_{5}$ & 0.0037 & 0.0006 & 0.0055 & 0.0009 & - & - & - & - & - & - & - & - & 0.0062 & 0.0075 & 0.0111 & 0.0054 \\
\hline $\mathrm{Cl} / \mathrm{P}_{2} \mathrm{O}_{5}$ & 0.0072 & 0.0024 & 0.0085 & 0.0028 & 0.0095 & 0.0027 & 0.0108 & 0.0030 & 0.0094 & 0.0031 & 0.0102 & 0.0026 & 0.0083 & 0.0032 & 0.0082 & 0.0009 \\
\hline $\mathrm{SO}_{3} / \mathrm{P}_{2} \mathrm{O}_{5}$ & 0.0013 & 0.0003 & 0.0022 & 0.0010 & 0.0021 & 0.0009 & 0.0014 & 0.0003 & 0.0014 & 0.0003 & 0.0012 & 0.0002 & 0.0020 & 0.0021 & 0.0038 & 0.0029 \\
\hline $\mathrm{MgO} / \mathrm{Na}_{2} \mathrm{O}$ & 0.41 & 0.06 & 0.39 & 0.12 & 0.35 & 0.13 & 0.25 & 0.02 & 0.36 & 0.04 & 0.24 & 0.04 & 0.42 & 0.05 & 0.24 & 0.04 \\
\hline
\end{tabular}

Table 2. Average chemical composition of dentin from modern and fossil hippopotamid molar teeth.

\begin{tabular}{|c|c|c|c|c|c|c|c|c|c|c|c|c|}
\hline Dentin & Lake Al & rt Modern & Lake M & vi Modern & Zoo S-2 & Modern & Nile & odern & Lake K & ongo Fossil & Lake Al & ert Fossil \\
\hline \multirow[t]{2}{*}{ Specimen/ Analyses } & \multicolumn{2}{|c|}{$1 / 25$} & \multicolumn{2}{|c|}{$1 / 20$} & \multicolumn{2}{|c|}{$1 / 13$} & \multicolumn{2}{|c|}{$1 / 6$} & \multicolumn{2}{|c|}{$1 / 23$} & \multicolumn{2}{|c|}{$14 / 136$} \\
\hline & Ave & $1 \sigma$ & Ave & $1 \sigma$ & Ave & $1 \sigma$ & Ave & $1 \sigma$ & Ave & $1 \sigma$ & Ave & $1 \sigma$ \\
\hline $\mathrm{P}_{2} \mathrm{O}_{5}$ & 42.52 & 1.29 & 38.05 & 0.74 & 44.45 & 0.62 & 38.65 & 1.06 & 36.64 & 5.14 & 38.29 & 2.20 \\
\hline $\mathrm{SiO}_{2}$ & $<0.04$ & - & 2.99 & 2.21 & 0.13 & 0.14 & $<0.04$ & - & 0.13 & 0.08 & 0.43 & 0.26 \\
\hline $\mathrm{FeO}$ & $<0.02$ & - & 0.05 & 0.01 & 0.08 & 0.03 & 0.06 & 0.01 & 0.21 & 0.13 & 3.55 & 4.40 \\
\hline $\mathrm{CaO}$ & 50.55 & 1.72 & 52.58 & 1.71 & 49.47 & 1.48 & 54.87 & 1.01 & 57.08 & 4.91 & 52.75 & 2.61 \\
\hline $\mathrm{MgO}$ & 3.41 & 0.44 & 2.53 & 0.58 & 2.38 & 0.89 & 3.00 & 0.12 & 0.93 & 0.72 & 0.19 & 0.05 \\
\hline $\mathrm{MnO}$ & $<0.05$ & - & $<0.05$ & - & $<0.05$ & - & $<0.05$ & - & 0.13 & 0.03 & 0.73 & 0.32 \\
\hline $\mathrm{SrO}$ & 0.09 & 0.02 & 0.09 & 0.01 & 0.08 & 0.02 & 0.03 & 0.01 & 0.72 & 0.15 & 0.20 & 0.06 \\
\hline $\mathrm{Na}_{2} \mathrm{O}$ & 1.12 & 0.09 & 1.36 & 0.11 & 1.11 & 0.10 & 1.14 & 0.07 & 1.00 & 0.23 & 0.55 & 0.07 \\
\hline $\mathrm{F}$ & 0.31 & 0.03 & 0.33 & 0.08 & 0.20 & 0.01 & $<0.02$ & - & 1.27 & 0.32 & 2.39 & 0.38 \\
\hline $\mathrm{Cl}$ & 0.06 & 0.01 & 0.09 & 0.03 & 0.22 & 0.05 & 0.11 & 0.01 & 0.09 & 0.04 & 0.03 & 0.01 \\
\hline $\mathrm{SO}_{3}$ & 0.28 & 0.05 & 0.34 & 0.03 & 0.47 & 0.06 & 0.36 & 0.07 & 0.25 & 0.05 & 0.32 & 0.27 \\
\hline $\mathrm{K}_{2} \mathrm{O}$ & 0.04 & 0.01 & 0.04 & 0.01 & 0.04 & 0.00 & 0.04 & 0.01 & 0.05 & 0.02 & 0.03 & 0.00 \\
\hline $\mathrm{Al}_{2} \mathrm{O}_{3}$ & $<0.03$ & - & 0.05 & 0.02 & 0.10 & 0.09 & 0.15 & 0.08 & 0.59 & 0.93 & 0.12 & 0.07 \\
\hline $\mathrm{H}_{2} \mathrm{O}$ & 1.64 & 0.02 & 1.59 & 0.03 & 1.72 & 0.02 & 1.68 & 0.01 & 1.16 & 0.11 & 0.53 & 0.48 \\
\hline Total & 70.80 & 2.35 & 77.76 & 2.10 & 75.27 & 1.28 & 77.49 & 2.13 & 82.08 & 7.17 & 88.61 & 4.91 \\
\hline $\mathrm{CaO} / \mathrm{P}_{2} \mathrm{O}_{5}$ & 1.19 & 0.08 & 1.38 & 0.03 & 1.11 & 0.05 & 1.42 & 0.06 & 1.62 & 0.50 & 1.38 & 0.05 \\
\hline $\mathrm{MgO} / \mathrm{P}_{2} \mathrm{O}_{5}$ & 0.0801 & 0.01 & 0.0667 & 0.0156 & 0.053 & 0.0198 & 0.0777 & 0.0041 & 0.0282 & 0.0296 & 0.0051 & 0.0016 \\
\hline $\mathrm{FeO} / \mathrm{P}_{2} \mathrm{O}_{5}$ & - & - & 0.0014 & 0.0002 & 0.0019 & 0.0008 & 0.0016 & 0.0001 & 0.0037 & 0.0035 & 0.0906 & 0.1093 \\
\hline $\mathrm{Na}_{2} \mathrm{O} / \mathrm{P}_{2} \mathrm{O}_{5}$ & 0.0262 & 0.0017 & 0.0358 & 0.0029 & 0.0249 & 0.0021 & 0.0295 & 0.0016 & 0.0274 & 0.0051 & 0.0147 & 0.0023 \\
\hline $\mathrm{F} / \mathrm{P}_{2} \mathrm{O}_{5}$ & 0.0073 & 0.0009 & 0.0086 & 0.0022 & 0.0066 & 0.0002 & - & - & 0.0352 & 0.0089 & 0.0612 & 0.0117 \\
\hline $\mathrm{Cl} / \mathrm{P}_{2} \mathrm{O}_{5}$ & 0.0014 & 0.0003 & 0.0023 & 0.0007 & 0.0049 & 0.0012 & 0.0030 & 0.0004 & 0.0022 & 0.0009 & 0.0009 & 0.0008 \\
\hline $\mathrm{SO}_{3} / \mathrm{P}_{2} \mathrm{O}_{5}$ & 0.0066 & 0.0013 & 0.0090 & 0.0007 & 0.0106 & 0.0013 & 0.0101 & 0.0015 & 0.0070 & 0.0013 & 0.0082 & 0.0072 \\
\hline $\mathrm{MgO} / \mathrm{Na}_{2} \mathrm{O}$ & 3.05 & 0.27 & 1.85 & 0.38 & 2.12 & 0.71 & 2.64 & 0.14 & 1.11 & 1.27 & 0.36 & 0.12 \\
\hline
\end{tabular}


Table 3. Average chemical composition of cement from modern and fossil hippopotamid molar teeth.

\begin{tabular}{|c|c|c|c|c|c|c|c|c|c|c|}
\hline \multirow{3}{*}{$\begin{array}{l}\text { Cement } \\
\text { Specimen/ Analyses }\end{array}$} & \multirow{2}{*}{\multicolumn{2}{|c|}{$\begin{array}{c}\text { Lake Albert Modern } \\
1 / 3\end{array}$}} & \multirow{2}{*}{\multicolumn{2}{|c|}{$\begin{array}{c}\text { Lake Malawi Modern } \\
1 / 5\end{array}$}} & \multirow{2}{*}{\multicolumn{2}{|c|}{$\begin{array}{c}\text { Zoo S-276 Modern } \\
1 / 16\end{array}$}} & \multirow{2}{*}{\multicolumn{2}{|c|}{$\begin{array}{c}\text { Lake Kikorongo Fossil } \\
1 / 6\end{array}$}} & \multirow{2}{*}{\multicolumn{2}{|c|}{$\begin{array}{c}\text { Lake Albert Fossil } \\
1 / 15\end{array}$}} \\
\hline & & & & & & & & & & \\
\hline & Ave & $1 \sigma$ & Ave & $1 \sigma$ & Ave & $1 \sigma$ & Ave & $1 \sigma$ & Ave & $1 \sigma$ \\
\hline $\mathrm{P}_{2} \mathrm{O}_{5}$ & 38.90 & 0.20 & 37.16 & 0.38 & 42.65 & 0.71 & 39.02 & 1.66 & 39.19 & 3.63 \\
\hline $\mathrm{SiO}_{2}$ & $<0.04$ & - & 2.00 & 0.49 & 0.51 & 0.45 & 1.24 & 0.54 & 0.66 & 0.65 \\
\hline $\mathrm{FeO}$ & $<0.02$ & - & 0.06 & 0.01 & 0.11 & 0.03 & 0.51 & 0.18 & 4.09 & 3.52 \\
\hline $\mathrm{CaO}$ & 56.42 & 0.25 & 55.65 & 0.66 & 51.62 & 0.67 & 54.16 & 0.53 & 52.11 & 3.02 \\
\hline $\mathrm{MgO}$ & 1.48 & 0.10 & 1.28 & 0.14 & 1.17 & 0.12 & 0.76 & 0.30 & 0.20 & 0.07 \\
\hline $\mathrm{MnO}$ & $<0.05$ & - & $<0.05$ & - & $<0.05$ & - & 0.08 & 0.01 & 0.59 & 0.20 \\
\hline $\mathrm{SrO}$ & 0.11 & 0.02 & 0.08 & 0.02 & 0.10 & 0.03 & 0.42 & 0.09 & 0.15 & 0.02 \\
\hline $\mathrm{Na}_{2} \mathrm{O}$ & 0.80 & 0.08 & 1.05 & 0.11 & 1.02 & 0.17 & 1.02 & 0.13 & 0.45 & 0.01 \\
\hline $\mathrm{F}$ & 0.34 & 0.05 & 0.66 & 0.14 & 0.15 & 0.05 & 0.67 & 0.21 & 2.97 & 0.29 \\
\hline $\mathrm{Cl}$ & 0.03 & 0.01 & 0.09 & 0.03 & 0.19 & 0.08 & 0.50 & 0.06 & 0.02 & 0.01 \\
\hline $\mathrm{SO}_{3}$ & 0.34 & 0.02 & 0.49 & 0.04 & 0.76 & 0.22 & 0.15 & 0.05 & 0.48 & 0.16 \\
\hline $\mathrm{K}_{2} \mathrm{O}$ & $<0.02$ & - & 0.05 & 0.01 & 0.04 & 0.02 & 0.14 & 0.05 & $<0.07$ & - \\
\hline $\mathrm{Al}_{2} \mathrm{O}_{3}$ & $<0.03$ & - & 0.05 & 0.00 & 0.27 & 0.15 & 0.06 & 0.02 & 0.07 & 0.03 \\
\hline $\mathrm{H}_{2} \mathrm{O}$ & 1.58 & 0.02 & 1.46 & 0.05 & 1.69 & 0.03 & 1.31 & 0.08 & 0.42 & 0.10 \\
\hline Total & 71.61 & 1.07 & 74.84 & 0.54 & 70.07 & 1.50 & 91.49 & 2.24 & 90.39 & 2.53 \\
\hline $\mathrm{CaO} / \mathrm{P}_{2} \mathrm{O}_{5}$ & 1.45 & 0.01 & 1.50 & 0.03 & 1.21 & 0.03 & 1.39 & 0.07 & 1.39 & 0.04 \\
\hline $\mathrm{MgO} / \mathrm{P}_{2} \mathrm{O}_{5}$ & 0.0379 & 0.0026 & 0.0344 & 0.0040 & 0.0274 & 0.0027 & 0.0198 & 0.0086 & 0.01 & 0.00 \\
\hline $\mathrm{FeO} / \mathrm{P}_{2} \mathrm{O}_{5}$ & - & - & 0.0016 & 0.0003 & 0.0025 & 0.0006 & 0.0131 & 0.0049 & 0.11 & 0.10 \\
\hline $\mathrm{Na}_{2} \mathrm{O} / \mathrm{P}_{2} \mathrm{O}_{5}$ & 0.0206 & 0.0020 & 0.0282 & 0.0029 & 0.0240 & 0.0041 & 0.0262 & 0.0043 & 0.01 & 0.00 \\
\hline $\mathrm{F} / \mathrm{P}_{2} \mathrm{O}_{5}$ & 0.0087 & 0.0014 & 0.0177 & 0.0038 & 0.0034 & 0.0011 & 0.0175 & 0.0060 & 0.08 & 0.01 \\
\hline $\mathrm{Cl} / \mathrm{P}_{2} \mathrm{O}_{5}$ & 0.0008 & 0.0003 & 0.0024 & 0.0008 & 0.0044 & 0.0019 & 0.0127 & 0.0011 & 0.00 & 0.00 \\
\hline $\mathrm{SO}_{3} / \mathrm{P}_{2} \mathrm{O}_{5}$ & 0.0088 & 0.0006 & 0.0131 & 0.0012 & 0.0179 & 0.0049 & 0.0040 & 0.0013 & 0.01 & 0.00 \\
\hline $\mathrm{MgO} / \mathrm{Na}_{2} \mathrm{O}$ & 1.85 & 0.18 & 1.23 & 0.21 & 1.17 & 0.21 & 0.74 & 0.25 & 0.45 & 0.14 \\
\hline
\end{tabular}

Chlorine content in modern and fossil enamel is overlapping ( $\sim 0.4 \mathrm{wt} . \%$ on average) and it is always higher than that in dentin and cement (Tables 1-3, Figs. 2, 3). However, the average $\mathrm{Cl}$ content in enamel varies by about $40 \%$. This rather large variation does not reflect differences among different teeth but is mainly due to intra enamel variation where concentrations may increase from 0.1 to $0.7 \mathrm{wt} . \% \mathrm{Cl}$ as one moves from the EDJ towards the outer rim (Fig. 4). This distribution can be observed all along the tooth crown (Fig. 2). The study of Kohn et al. (1999) describes a similar concentration range in different regions of enamel from fossil Hippopotamids and studies on other mammal teeth corroborate these observations (Norén et al., 1983; Driessens et al., 1990).

Modern tooth material has low F contents (0.1.-0.7 wt. \%; Tables 1, 2, 3; Fig. 3) and it represents with regard to its halogen abundances $(\mathrm{Cl}, \mathrm{F}, \mathrm{OH})$ the composition of hydroxyapatite. Fossil material has systematically higher $\mathrm{F}$ contents than the modern examples. This is particularly true for fossil cement and dentin which are enriched by containing on average about $2 \mathrm{wt}$. \% of F (Fig. 3). This concentration contrast between enamel and cement and dentin is clearly seen along profiles (Fig. 4). Within the enamel, the distribution of $\mathrm{F}$ differs among modern and fossil material. In modern enamel, F contents stay rather constant or decrease from the EDJ towards the outside. Previous studies on human, monkey, rat or porcupine enamel, however, observed the opposite trend (Norén et al., 1983; Driessens et al., 1990). Such a distribution pattern is displayed in most of our fossil enamel material (Fig. 4); however, we also find an U-shape distribution where the central enamel region has the lowest F contents (Fig. 4). Even in these cases, the outer rim has always the highest $\mathrm{F}$ contents.

In modern specimens concentration of the remaining analyzed components $\left(\mathrm{SrO}, \mathrm{FeO}, \mathrm{MnO}, \mathrm{K}_{2} \mathrm{O}, \mathrm{SiO}_{2}, \mathrm{Al}_{2} \mathrm{O}_{3}\right.$, and $\mathrm{SO}_{3}$ ) are consistently very low, often close to or below the detection limits, so that the relationships between the different tooth regions cannot be reasonably well resolved (Tables 1, 2, 3). Whereas modern tooth parts and fossil enamel have on average similar $\mathrm{SrO}$ contents, the concentrations in fossil dentin and cement are higher and more variable (Fig. 3). One specimen stands out (Lake Kikorongo) because it has consistently higher $\mathrm{SrO}$ contents, which are 3 times higher in enamel compared to all other samples (Table 1; Fig. 4). Fossil materials, in particular dentin and cement, are highly enriched in $\mathrm{FeO}$ and $\mathrm{MnO}$ and show large variations of concentrations ( $>50 \%$; Tables $1,2,3$; Fig. 3 ). Variable $\mathrm{FeO}$ contents are easily recognized macroscopically 


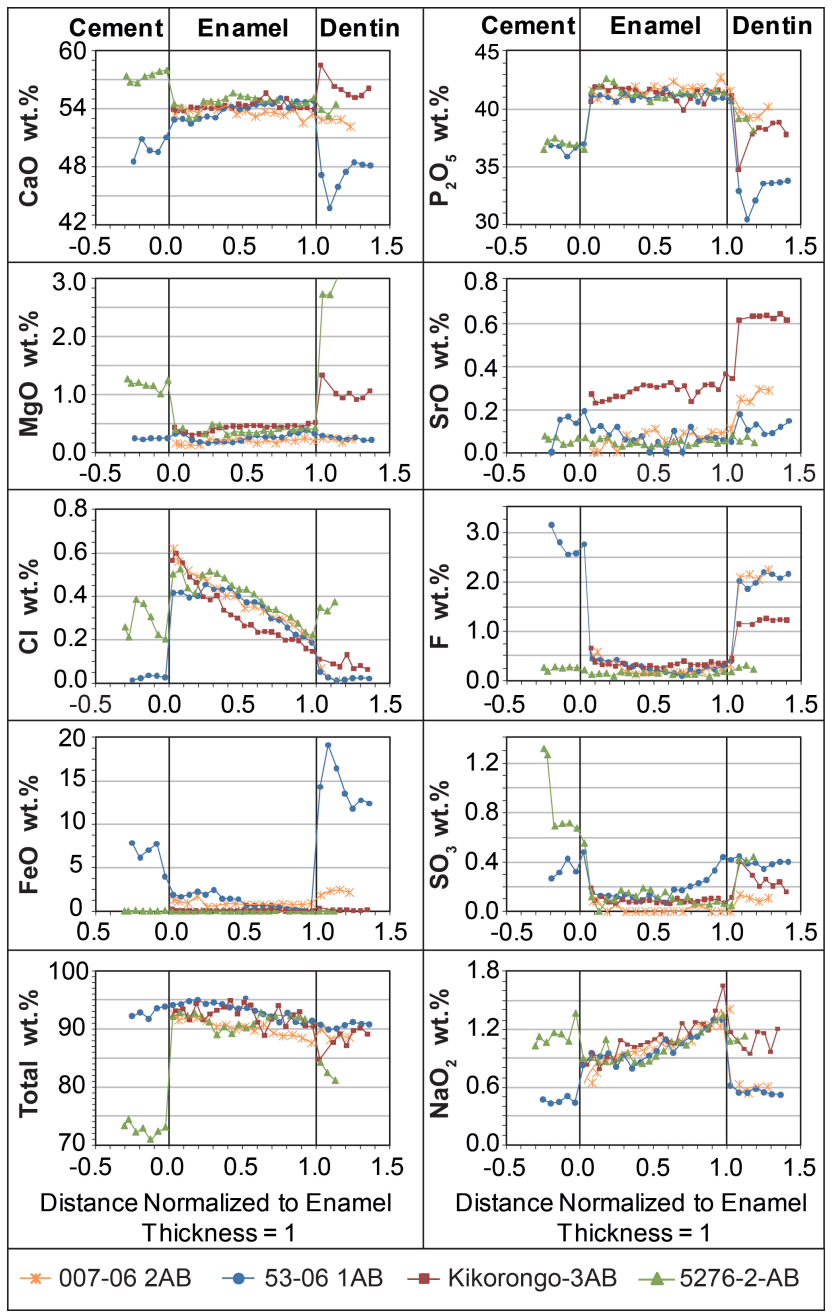

Fig. 4. Chemical variations along selected profiles of molar teeth from the outside margin through cementum, enamel into dentin. Note the different concentrations in enamel, cement and dentin, but similar element distribution patterns in enamel from modern (Zoo S276, M3) and fossil specimen from Lake Albert (00706, molar frag; 5306, molar frag.) and Lake Kikorongo, (M3). The distance is normalized to the length of the enamel $=1$. Location of the profiles is shown in Fig. 1. Data are given in Tables S1-4 in the Supplement.

by the different coloring of the teeth samples (Fig. 1). Modern tooth material is entirely white and concentrations of $\mathrm{FeO}$ and $\mathrm{MnO}$ are below 0.1 wt. \% (Tables 1, 2, 3). Fossil dentin and cement and to a lesser degree enamel are characterized by light to dark brown staining and may contain up to 24 wt. \% FeO and 1.4 wt. \% $\mathrm{MnO}$ (sample 053-06; Table 2 and Fig. 4). The $\mathrm{FeO}$ distribution in fossil enamel is systematic in that concentration can increase from detection limit at the EDJ towards wt. \% levels at the enamel rim (Fig. 4).

The very low concentrations of $\mathrm{K}_{2} \mathrm{O}, \mathrm{SiO}_{2}$, and $\mathrm{Al}_{2} \mathrm{O}_{3}$ in modern and fossil materials indicate that crystallization or mechanical introduction of silicate phases into the fossil dur- ing diagenesis is not of importance. These components will not be discussed further on.

\section{Discussion}

Teeth are composite materials consisting of organic and inorganic components which undergo profound changes in chemistry and structure during growth and eventually during fossil diagenesis (Robinson et al., 1995; Smith, 1998; Kohn et al., 1999; Boskey, 2007). In the following, we decipher the chemical signatures preset during the growth of the tooth and later on superimposed during fossilization. This is done by comparing the chemical composition of modern and fossil material on the basis of the bulk composition as well as on the element distribution observed across enamel and dentin growth structures. These comparisons are supported by statistical methods such as linear regression analysis and single factor analysis of variance (ANOVA). However, the compositions of dentin and cement are highly variable. No systematic concentration relationships between these materials can be observed and ANOVA does not reveal significant differences among tooth populations.

In order to generalize the observation made on the distribution of the major elements and to compare the compositions of enamel of different geological age and habitat, the relationship between concentration and enamel thickness $(x)$ are quantified by linear regression analysis for each EDJ-rim profile in each specimen (number of profiles: 18 modern, 42 fossil). In order to account for variable thickness of enamel in large and small teeth and various regions of a tooth, enamel thickness along measurement transects has been normalized from $x=0$ to 1 . For each regression line, the coefficient of determination $\left(R^{2}\right)$, the slope $(m)$ and the enamel composition at the outer rim $(x=0)$ and at the $\operatorname{EDJ}(x=1)$ have been calculated. The result of the analysis is given in Table 4 which summarizes the average value and standard deviations of each parameter for all modern specimens, for fossil specimens from Lake Albert and from Lake Kikorongo.

In order to decipher differences among various tooth populations we applied single factor analysis of variance (ANOVA). The data set has been divided into 3 main populations, modern enamel, enamel from Lake Kikorongo and enamel from fossil Lake Albert. The variances of the elements were then compared using the concentration values determined by the regression analysis close to the EDJ ( $x=1$ in Table 4). The results are shown in Table 5 indicating that there are significant differences $(\alpha<0.05)$ for $\mathrm{MgO}$, SrO, $\mathrm{Na}_{2} \mathrm{O}, \mathrm{Cl}, \mathrm{F}$ and $\mathrm{FeO}$ among the 3 sample populations, but this cannot be verified for the measured Total, $\mathrm{CaO}, \mathrm{P}_{2} \mathrm{O}_{5}$ and $\mathrm{SO}_{3}$. The Scheffé test is applied to determine which population pairs cause the significant differences suggested by ANOVA. As a first approach the results can be used to subdivide the elements into 2 groups: distributions which are considerably influenced by post-mortem processes $\left(\mathrm{SO}_{3}, \mathrm{~F}\right.$ 

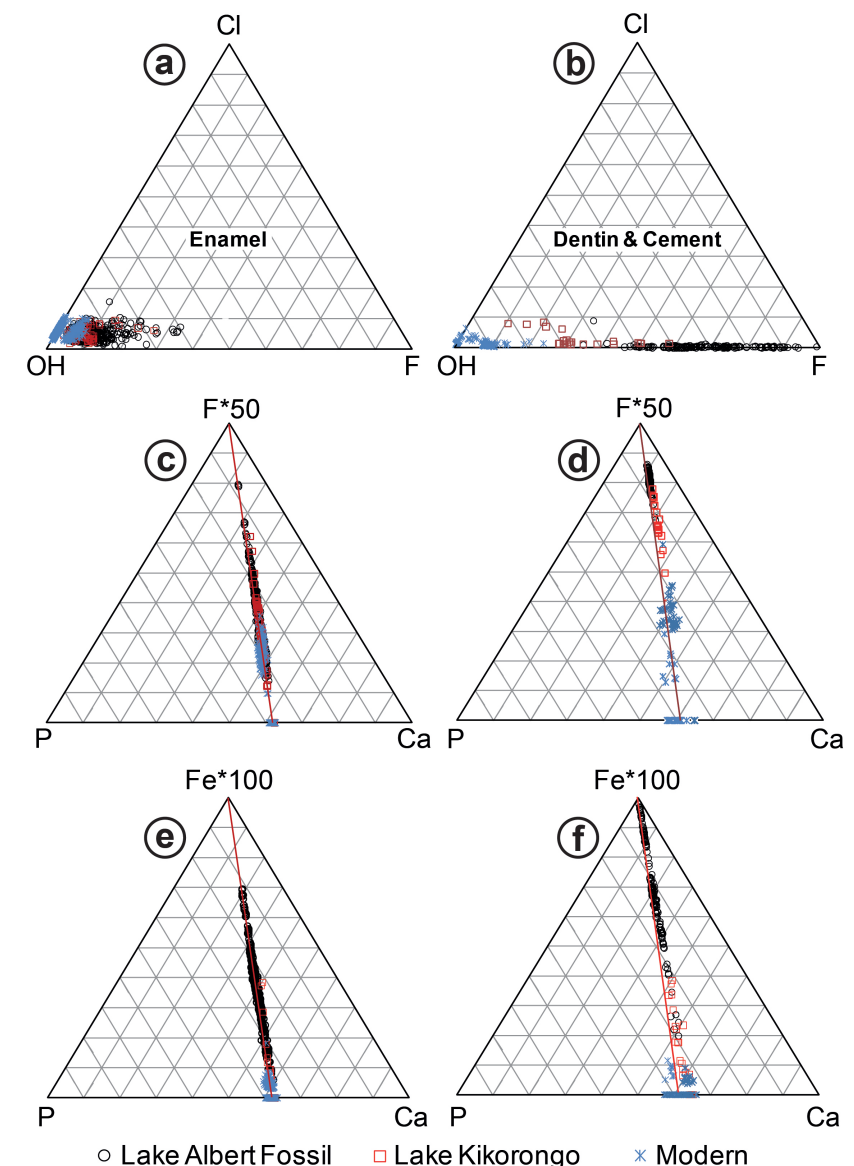

○ Lake AlbertFossil $\square$ Lake Kikorongo $*$ Modern

Fig. 5. Chemical components (atomic proportions) in enamel, dentin and cement of modern and fossil Hippopotamid molar teeth indicating the addition of $\mathrm{FeO}$ and $\mathrm{F}$ during post-mortem alteration processes. (a), (c), (e): distribution of $\mathrm{Cl}-\mathrm{F}-\mathrm{OH}, \mathrm{F} * 50-\mathrm{Ca}-\mathrm{P}$, $\mathrm{Fe}^{*} 100-\mathrm{Ca}-\mathrm{P}$, respectively, in enamel. (b), (d), (e): distribution of Cl-F-OH, F*50-Ca-P, Fe*100-Ca-P, respectively, in dentin and cement. Red line defines the trend of modern enamel having a rather constant $\mathrm{Ca} / \mathrm{P}$.

and $\mathrm{FeO}$ ) and distributions which dominantly reflect in vivo processes $\left(\mathrm{MgO}, \mathrm{Na}_{2} \mathrm{O}, \mathrm{Cl}, \mathrm{CaO}, \mathrm{P}_{2} \mathrm{O}_{5}\right)$.

\subsection{Chemical characteristics of Hippopotamid teeth: recognizing post-mortem alteration}

An obvious visual difference between modern and fossil teeth is their coloring (Fig. 1): fossil material, in particular dentin, shows a brown staining which is caused by high $\mathrm{FeO}$ and $\mathrm{MnO}$ contents. The $\mathrm{FeO}$ addition becomes apparent if one compares the most abundant components in a Ca-P-Fe triangle diagram, where fossil enamel follows a Fe-enrichment trend of constant $\mathrm{Ca} / \mathrm{P}$ ratio $(\mathrm{P} / \mathrm{Ca}=0.604 \pm 0.012$; Fig. 5$)$. This ratio is indistinguishable from that in modern Hippopotamid enamel $(\mathrm{P} / \mathrm{Ca}=0.618 \pm 0.018)$. Fossil dentin and cement tend to have lower $\mathrm{P} / \mathrm{Ca}$ ratios $(0.57 \pm 0.02)$ than enamel but the enrichment in $\mathrm{Fe}$ also follows a trend with a constant $\mathrm{P} / \mathrm{Ca}$ ratio (Fig. 5). The Fe distribution in teeth is systematic in that $\mathrm{FeO}$ decreases from the outside enamel rim towards the EDJ in fossil enamel and a distinct concentration increase at the interfaces of enamel with dentin and cement (Fig. 4). The backscattered image of modern enamel is significantly brighter than that of dentin, whereas the opposite is observed in fossil teeth (Fig. 2). This has also been reported by others (Kohn et al., 1999; Jacques et al., 2008) and reflects different average atomic numbers of the materials. Modern dentin and cement have lower concentrations of $\mathrm{CaO}$ and higher concentrations of interstitial organic material than enamel and therefore have lower average atomic numbers than enamel. The higher atomic number for fossil dentin must reflect a higher concentration of elements with high atomic numbers, such as $\mathrm{Fe}$ and $\mathrm{Mn}$. These observations all together indicate impregnation of the tooth by Fe-Mn-bearing solutions which resulted in the precipitation of submicron sized, interstitial $\mathrm{Fe}$ - and Mn-oxides and oxyhydroxides starting from the outside tooth rim (Kohn et al., 1999).

The other important chemical change observed in fossil teeth involves the post-mortem addition of F. In terms of its nomenclature the apatite composition varies from hydroxyapatite in modern material to fluorapatite in fossil examples (Fig. 5). The F content in modern enamel is significantly different from fossil enamel but no significant difference can be recognized between the fossil samples from Lake Kikorongo and Lake Albert having significantly different geological ages (Table 5) supporting the above contention of secondary $\mathrm{F}$ addition. The preferred incorporation of $\mathrm{F}$ is expected because its small ionic radius allows easy access into the crystal lattice of hydroxyapatite and because fluorapatite is less soluble and therefore more stable in the low temperature environment than hydroxyapatite (Aoba, 1997; Wopenka and Pasteris, 2005). In human teeth increasing F contents and a systematic increase from the EDJ towards the outer rim have been positively correlated with nutritional intake (Buddecke, 1981). This distribution pattern has not been observed in modern Hippopotamid enamel; even the opposite trend is displayed in profiles of the Malawi specimen. The $\mathrm{F}$ distribution along many fossil enamel profiles shows a U-shape pattern. Although this pattern may contain a primary fingerprint, it appears to be dominated by secondary $\mathrm{F}$ addition through diffusive migration of the pore fluids into the tooth. Such processes have been discussed by Millard and Hedges (1996) and Kohn (2008) in order to explain similar distribution patterns in fossil bones and teeth. Analogous to the $\mathrm{Fe}$ trend $\mathrm{F}$ enrichment occurs without changing the P/Ca ratio (Fig. 5c, d). This implies that no other $\mathrm{Ca}$ - or P-bearing phase, such as fluorite $\left(\mathrm{CaF}_{2}\right)$ or vivianite $\left(\mathrm{Fe}_{3}^{2+}\left(\mathrm{PO}_{4}\right)_{2} 8\left(\mathrm{H}_{2} \mathrm{O}\right)\right)$, has been introduced or crystallized during fossilization and diagenesis. Thus, low $\mathrm{P}_{2} \mathrm{O}_{5}$ and $\mathrm{CaO}$ contents in fossil enamel are solely due to their "dilution" by other components such as $\mathrm{F}$ and $\mathrm{FeO}$. 
Table 4. Regression analysis of the element distribution in enamel along profiles from the outer enamel rim $(x=0)$ towards the enamel-dentin junction $(x=1)$.

\begin{tabular}{|c|c|c|c|c|c|c|c|c|}
\hline \multirow{4}{*}{$\begin{array}{l}\text { Sample } \\
\text { Modern Ave } \\
\text { Fossil L-Albert Ave } \\
\text { Kikorongo Ave }\end{array}$} & \multirow{4}{*}{$\begin{array}{c}\text { Element } \\
\text { Total }\end{array}$} & \multirow{4}{*}{$\begin{array}{l}* R^{2} \\
0.51 \\
0.63 \\
0.54\end{array}$} & \multirow{4}{*}{$\begin{array}{l}* * m \\
-2.40 \\
-2.59 \\
-2.04\end{array}$} & \multicolumn{2}{|c|}{$X=1 \mathrm{EDJ}$} & \multicolumn{2}{|c|}{$X=0$ Outer Enamel } & \multirow{4}{*}{$\begin{array}{c}\% x 1-x 0 \\
-2.63 \\
-2.84 \\
-2.21\end{array}$} \\
\hline & & & & 91.33 & $(1.00)^{* * *}$ & 93.73 & (1.04) & \\
\hline & & & & 91.42 & $(1.35)$ & 94.01 & (1.18) & \\
\hline & & & & 92.56 & $(0.77)$ & 94.60 & $(0.39)$ & \\
\hline Modern Ave & $\mathrm{CaO}$ & 0.15 & -0.11 & 54.06 & $(0.78)$ & 54.17 & $(0.46)$ & -0.22 \\
\hline Fossil L-Albert Ave & & 0.17 & -0.01 & 54.05 & $(0.58)$ & 54.06 & $(0.49)$ & -0.03 \\
\hline Kikorongo Ave & & 0.32 & -0.54 & 54.01 & $(0.24)$ & 54.55 & $(0.11)$ & -1.01 \\
\hline Modern Ave & $\mathrm{P}_{2} \mathrm{O}_{5}$ & 0.16 & -0.31 & 41.97 & $(0.93)$ & 42.28 & $(0.59)$ & -0.76 \\
\hline Fossil L-Albert Ave & & 0.16 & -0.08 & 41.45 & $(0.35)$ & 41.52 & $(0.37)$ & -0.19 \\
\hline Kikorongo Ave & & 0.11 & -0.10 & 41.47 & $(0.47)$ & 41.58 & $(0.17)$ & -0.25 \\
\hline Modern Ave & $\mathrm{MgO}$ & 0.58 & 0.17 & 0.44 & $(0.11)$ & 0.27 & $(0.07)$ & 37.9 \\
\hline Fossil L-Albert Ave & & 0.44 & 0.09 & 0.26 & $(0.03)$ & 0.18 & $(0.03)$ & 32.1 \\
\hline Kikorongo Ave & & 0.75 & 0.23 & 0.56 & $(0.08)$ & 0.33 & $(0.03)$ & 40.6 \\
\hline Modern Ave & $\mathrm{SrO}$ & 0.14 & 0.02 & 0.07 & $(0.02)$ & 0.05 & $(0.02)$ & 30.0 \\
\hline Fossil L-Albert Ave & & 0.20 & 0.04 & 0.08 & $(0.03)$ & 0.04 & $(0.02)$ & 20.3 \\
\hline Kikorongo Ave & & 0.76 & 0.21 & 0.49 & $(0.11)$ & 0.27 & $(0.03)$ & 42.7 \\
\hline Modern Ave & $\mathrm{Na}_{2} \mathrm{O}$ & 0.84 & 0.56 & 1.35 & $(0.12)$ & 0.79 & $(0.08)$ & 40.9 \\
\hline Fossil L-Albert Ave & & 0.85 & 0.53 & 1.21 & $(0.10)$ & 0.68 & $(0.10)$ & 43.8 \\
\hline Kikorongo Ave & & 0.90 & 0.60 & 1.39 & $(0.14)$ & 0.79 & $(0.02)$ & 42.6 \\
\hline Modern Ave & $\mathrm{Cl}$ & 0.95 & -0.41 & 0.20 & $(0.05)$ & 0.61 & $(0.05)$ & -223 \\
\hline Fossil L-Albert Ave & & 0.93 & -0.38 & 0.16 & $(0.05)$ & 0.54 & $(0.06)$ & -293 \\
\hline Kikorongo Ave & & 0.97 & -0.40 & 0.13 & $(0.01)$ & 0.53 & $(0.03)$ & -308 \\
\hline Modern Ave & $\mathrm{F}$ & 0.13 & 0.00 & 0.08 & $(0.11)$ & 0.20 & $(0.02)$ & -3.5 \\
\hline Fossil L-Albert Ave & & 0.31 & 0.00 & 0.37 & $(0.20)$ & 0.37 & $(0.25)$ & -20.1 \\
\hline Kikorongo Ave & & 0.31 & 0.12 & 0.32 & $(0.10)$ & 0.20 & $(0.06)$ & 38.2 \\
\hline Modern Ave & $\mathrm{SO}_{3}$ & 0.11 & -0.03 & 0.03 & $(0.04)$ & 0.06 & $(0.04)$ & 238 \\
\hline Fossil L-Albert Ave & & 0.24 & -0.02 & 0.09 & $(0.12)$ & 0.18 & $(0.16)$ & -189 \\
\hline Kikorongo Ave & & 0.10 & 0.01 & 0.08 & $(0.01)$ & 0.07 & $(0.02)$ & 10.3 \\
\hline Modern Ave & $\mathrm{FeO}$ & 0.03 & 0.00 & 0.01 & $(0.01)$ & 0.01 & $(0.01)$ & -130 \\
\hline Fossil L-Albert Ave & & 0.39 & -0.16 & 0.55 & $(0.33)$ & 0.71 & $(0.45)$ & 99 \\
\hline Kikorongo Ave & & 0.09 & -0.02 & 0.02 & $(0.01)$ & 0.04 & $(0.05)$ & -166 \\
\hline
\end{tabular}

$* R^{2}$ : coefficient of determination;

$* * m$ : slope of regression line;

$* * *$ Values in parentheses: $1 \sigma$

The $\mathrm{SO}_{3}$ concentration in teeth material is highly variable (Fig. 3) and ANOVA cannot distinguish teeth populations (Table 5). However, $\mathrm{SO}_{3}$ concentrations in fossil enamel tend to be higher than in modern enamel (Fig. 3; Table 4) and there is a significant correlation between $\mathrm{SO}_{3}$ and $\mathrm{F}$ contents in fossil enamel $\left(R^{2}=0.43, p<0.0001\right)$, but not in modern material. The distribution pattern of $\mathrm{F}$ and $\mathrm{SO}_{3}$ along profiles of fossil specimens is also similar (Fig. 4), although no overall trend can be recognized (Table 4). This suggests that the $\mathrm{SO}_{3}$ content and distribution in the teeth have also been significantly modified during diagenesis.

The $\mathrm{FeO}, \mathrm{F}$ and $\mathrm{SO}_{3}$ contents do not systematically change with the geological age of the Hippopotamid teeth. This implies that local sedimentary factors influencing the mobilization of these components, such as rock composition, $\mathrm{pH}$ value and redox potential, control the introduction of these elements into the tooth materials during fossilization, rather than chemical exchange on large time scales. With regard to the $\mathrm{FeO}$ content of fossil samples, those from Lake Kikorongo appear to be distinct because they have much lower contents of $\mathrm{FeO}, \mathrm{F}$ and $\mathrm{SO}_{3}$ than fossil teeth from Lake Albert (Table 4). This difference probably reflects the depositional environment in which the teeth have been fossilized. Throughout its history Lake Albert has been a freshwater lake (Pickford et al., 1993). In contrast, the water of Lake Kikorongo is saline and alkaline representing an environment 
Table 5. One Factor analysis of variance (ANOVA) of molar enamel and Scheffé tests distinguishing modern, Lake Kikorongo and fossil Lake Albert populations.

\begin{tabular}{lllll}
\hline & ANOVA p-value & Scheffé test p-value & Scheffé test p-value & Scheffé test p-value \\
\hline \multirow{3}{*}{$\alpha=0.05$} & 3 populations: & 2 populations: & 2 populations: & 2 populations: \\
-Modern & -Modern & -Modern & -Fossil \\
& -Kikorongo & -Fossil & -Kikorongo & L. Albert \\
& -Fossil & L. Albert & & -Kikorongo \\
L. Albert & & & \\
\hline
\end{tabular}

\begin{tabular}{lrrrr}
\hline Total & 0.2982 & & & \\
$\mathrm{CaO}$ & 0.9600 & & & \\
$\mathrm{P}_{2} \mathrm{O}_{5}$ & 0.0571 & $\mathbf{0 . 0 0 0 2}$ & $\mathbf{0 . 0 0 8 1}$ & $<\mathbf{0 . 0 0 0 1}$ \\
$\mathrm{MgO}$ & $*<\mathbf{0 . 0 0 0 1}$ & $\mathbf{0 . 0 2 8 5}$ & $\mathbf{0 . 0 0 0 0}$ & $<\mathbf{0 . 0 0 0 1}$ \\
$\mathrm{Sr}$ & $<\mathbf{0 . 0 0 0 1}$ & $\mathbf{0 . 0 0 0 3}$ & 0.2895 & $\mathbf{0 . 0 0 4 5}$ \\
$\mathrm{Na}_{2} \mathrm{O}$ & $\mathbf{0 . 0 0 0 7}$ & $\mathbf{0 . 0 1 8 6}$ & $\mathbf{0 . 0 2 0 2}$ & 0.1696 \\
$\mathrm{Cl}$ & $\mathbf{0 . 0 4 5 1}$ & $<\mathbf{0 . 0 0 0 1}$ & $\mathbf{0 . 0 1 8 4}$ & 0.2950 \\
$\mathrm{~F}$ & $\mathbf{0 . 0 0 0 1}$ & & & \\
$\mathrm{SO}_{3}$ & 0.2547 & $<\mathbf{0 . 0 0 0 1}$ & 0.4893 & $\mathbf{0 . 0 0 1 2}$ \\
$\mathrm{FeO}$ & $<\mathbf{0 . 0 0 0 1}$ & & & \\
\hline
\end{tabular}

* bold numbers: at $P<0.05$ different population means, rejecting the $\mathrm{H}_{0}$ hypothesis of equal variances.

where $\mathrm{FeO}$ mobilization is limited. Hence, although these elements bear little information on the diet of Hippopotamids, post-mortem concentration changes in fossil teeth may provide information on past ecological changes, because the mobility of the element in the local pore water is affected by climate parameters such as temperature or precipitation.

\subsection{Chemical characteristics of dentin and cement from Hippopotamid teeth}

Dentin and cement exhibit a rather "spongy" texture and for this reason these materials become severely altered during diagenesis. This has been clearly documented for elements like $\mathrm{F}$ and $\mathrm{Fe}$ (see discussion in previous chapter). However, the influence of diagenesis cannot be unambiguously evaluated for major and minor components $\left(\mathrm{CaO}, \mathrm{Na}_{2} \mathrm{O}\right.$, $\mathrm{MgO}, \mathrm{Cl}, \mathrm{P}_{2} \mathrm{O}_{5}$ ) because we have not systematically investigated the composition of dentin and cement along specific growth structures. The composition of dentin and cement differ from enamel even among modern teeth which becomes obvious along profiles from the outer margin of the tooth crown towards and into the dentin (Fig. 4). The interface between enamel and dentin or enamel and cement is narrow $(<100 \mu \mathrm{m})$ and well defined for most elements. The pattern of concentration change across the dentin-enamel and cement-enamel has the same trend for individual elements, although with different magnitudes. Dentin and cement are depleted in $\mathrm{CaO}$ and $\mathrm{Cl}$, but are enriched in $\mathrm{MgO}$ and $\mathrm{P}_{2} \mathrm{O}_{5}$ relative to enamel (Fig. 4). One exception appears to be $\mathrm{Na}_{2} \mathrm{O}$, which is depleted in dentin but enriched in cement relative to enamel. However, there are no systematic variations along the profiles within dentin and cement which appear to be inhomogeneous on the scale of ten's of micrometers. The low total sum of the chemical analysis in dentin and cement compared to enamel (Fig. 4) reflects their lower mineral proportion relative to the organic matrices. This, however, does not explain the variable $\mathrm{CaO} / \mathrm{P}_{2} \mathrm{O}_{5}$ ratios as indicated by the atomic proportions of the elements (Fig. 6) and which differ from that of enamel.

Although there are large concentration variations in and between modern dentin and cement, the relative atomic proportions of the main components are very similar and in these terms fundamental chemical/mineralogical differences between these two materials cannot be deciphered. The $\mathrm{Na}$ variation is relatively small (Fig. 6) and comparable to that in enamel which indicates that this element is very well controlled by metabolic processes. However, $\mathrm{Cl}$ and $\mathrm{Mg}$ in dentin and cement vary substantially and appear to delineate different habitats. For example, cement and dentin from Lake Malawi Hippopotamid are enriched in $\mathrm{Mg}$, whereas the material from the zoo animal is enriched in $\mathrm{Cl}$ relative to the other samples (Fig. 6). The $\mathrm{Na} / \mathrm{Ca}$ ratio and the variation of $\mathrm{Mg} / \mathrm{Na}$ ratio in modern cement and dentin is similar to that of enamel and distinguishes different environments (Fig. 6). Nonetheless, the pattern displayed by this material is different from that of enamel. Whereas enamel from the Nile River Hippopotamid has a distinctively high $\mathrm{Na} / \mathrm{Mg}$ and the zoo enamel has the lowest $\mathrm{Na} / \mathrm{Mg}$ ratio, dentin and cement from the zoo animal have the highest $\mathrm{Na} / \mathrm{Mg}$ ratio (compare Figs. 6d and 7d). These differences are difficult to reconcile. One plausible explanation is that the timing of the mineralization of dentin and cement differs from that of enamel which may result in different chemical signatures, perhaps further accentuated by changing environmental and 
nutritional factors. However, a potential influence of alteration has to be kept in mind.

The range of minor element concentrations in fossil dentin and cement overlaps with and in cases extends that of modern specimens (Fig. 6). The proportions of $\mathrm{Na}, \mathrm{Mg}$ and $\mathrm{Cl}$ in the specimen of Lake Kikorongo are higher than those in fossils from Lake Albert. However, the contents of these elements in material from Lake Kikorongo overlap with those in the modern specimen, which suggests that they do not necessarily reflect element enrichments indicative for a saline ecosystem. The concentration in the fossil material from Lake Albert, on the other side, has lower concentration than the modern one. In particular, the low Na proportion in fossils from Lake Albert is reflected in the high $\mathrm{Ca} / \mathrm{Na}$ ratio shown in Fig. 6h, whereas materials from Lake Kikorongo plot along the line defined by enamel and modern cement and dentin. Thus, a reasonable explanation is that the fossil material lost $\mathrm{Mg}, \mathrm{Na}$ and $\mathrm{Cl}$ during fossilization.

\subsection{Chemical characteristics of Hippopotamid tooth enamel: recognizing the in-vivo control on element distribution}

The distribution of the principal components $\left(\mathrm{P}_{2} \mathrm{O}_{5}, \mathrm{CaO}\right.$, $\mathrm{MgO}, \mathrm{Na}_{2} \mathrm{O}, \mathrm{Cl}$ ) is similar in fossil and modern enamel and is little disturbed by secondary processes. For example, the slopes calculated with the regression analyses are similar for individual elements regardless of the origin and the geological age of the tooth (Fig. 4; Table 4). In some cases minor enrichment or depletion of these elements exists near the outer enamel rim (Fig. 4) indicating minor mobilization during diagenesis. In contrast, near the EDJ concentration variations are small (Table 4). The EDJ is well defined showing no gradual concentration change into the dentin (Fig. 4) which implies very limited chemical exchange or migration by diffusion between enamel and dentin. Thus, the most preferred sampling site for chemical analysis, if focusing on the unaltered, primary fingerprint, is enamel close to the EDJ (i.e. $x=1$ in Table 4 ).

In particular the relative atomic proportions of the main components are indistinguishable in fossil and modern enamel (Fig. 7). The molar P/Ca ratio in modern enamel is overall well constrained and varies within tight limits $(0.618 \pm 0.018$; Fig. 7) showing no clear dependency with tooth growth. Fossil enamel displays the same P/Ca variation $(0.604 \pm 0.012)$ and ANOVA could not identify significant differences $(p<0.05)$ among enamel populations (Table 5). Similarly, the ranges of the atomic proportions of $\mathrm{Mg}, \mathrm{Na}$ and $\mathrm{Cl}$ in enamel from fossil samples overlaps with that of modern enamel (Fig. 7). The overall limited variation in major and minor elements is also confirmed by ANOVA, which cannot distinguish different enamel populations by means of the Total of all measured components (Table 5). This Total decreases from the outer margin towards the EDJ in fossil and modern enamel to similar degrees $(\sim 2.5 \mathrm{wt}$. \%; Total in
Fig. 4 and Tables 1-5). One important chemical component not included in our measurement is the carbonate content of the enamel. Considering data from other mammals, carbonate shows the opposite behavior, decreasing from the EDJ towards the outside (Verbeeck et al., 1985; Aoba and Moreno, 1990; Zazzo et al., 2005) which would compensate the variation of the Total we measured. Therefore, diagenesis or postmortem recrystallization has not significantly altered the major components of fossil enamel, which might also explain why oxygen or carbon isotopic studies on enamel are most successful tools in revealing paleoclimate and environmental changes.

The variation of the main components along the profiles follows three patterns. $\mathrm{CaO}$ and $\mathrm{P}_{2} \mathrm{O}_{5}$ show flat trends along the profiles from all specimens and therefore the concentrations at the inner and outer enamel rims overlap, within analytical error (Table 4). $\mathrm{Na}_{2} \mathrm{O}$ and $\mathrm{MgO}$ display always positive slopes from the enamel rim towards the EDJ, whereas $\mathrm{Cl}$ always follows a negative trend. These three components have the highest $R^{2}$ factor among all studied elements (Table 4), which implies that during enamel growth their distribution is well controlled and follows the same laws in fossil as well as in modern animals. Ratios such as $\mathrm{Na} / \mathrm{P}$, $\mathrm{Na} / \mathrm{Ca}, \mathrm{Mg} / \mathrm{P}$, or $\mathrm{Mg} / \mathrm{Ca}$ are not constant but systematically increase along constant $\mathrm{Ca} / \mathrm{P}$ ratios from the outer rim towards the EDJ (Fig. 7). This means that in order to draw meaningful conclusions about changing nutritional intake, equivalent sample locations within the enamel body have to be compared.

In summary, the compositional variations of $\mathrm{P}_{2} \mathrm{O}_{5}$ and $\mathrm{CaO}$ are decoupled from the variation of $\mathrm{Na}_{2} \mathrm{O}, \mathrm{MgO}$ or $\mathrm{Cl}$ which implies different control mechanisms during the process of enamel formation. In addition, there is the remarkable feature that the general concentration trends of $\mathrm{Na}_{2} \mathrm{O}, \mathrm{MgO}$ or $\mathrm{Cl}$ across different enamel profiles are similar, but the concentrations of the three elements follow different slopes and the variations from the enamel rim to the EDJ are large ranging from about $40 \%$ for $\mathrm{MgO}$ and $\mathrm{Na}_{2} \mathrm{O}$ to more than $200 \%$ for $\mathrm{Cl}$ (Table 4). Hence, two principle questions arise: (1) what controls the different slopes of the element distribution along the enamel profile, and (2) what determines the degree of enrichment of $\mathrm{MgO}$ and $\mathrm{Na}_{2} \mathrm{O}$ or depletion of $\mathrm{Cl}$ during the formation of enamel?

\subsubsection{Recognizing discrete sedimentary environments}

Abrupt chemical changes along the enamel profiles have never been observed in our specimens. This implies that major changes of diet have not occurred and that individual animals did not move to substantially different habitats during the time of enamel formation. This had been anticipated considering the autochthonous behavior of hippopotamuses. The small variation of average concentration of $\mathrm{CaO}, \mathrm{P}_{2} \mathrm{O}_{5}$ and the tightly defined distribution pattern $\left(R^{2}>0.8\right)$ with similar $\mathrm{Cl}$ and $\mathrm{Na}_{2} \mathrm{O}$ variations across all profiles (Figs. 4, 


\section{Modern Dentin \& Cement}
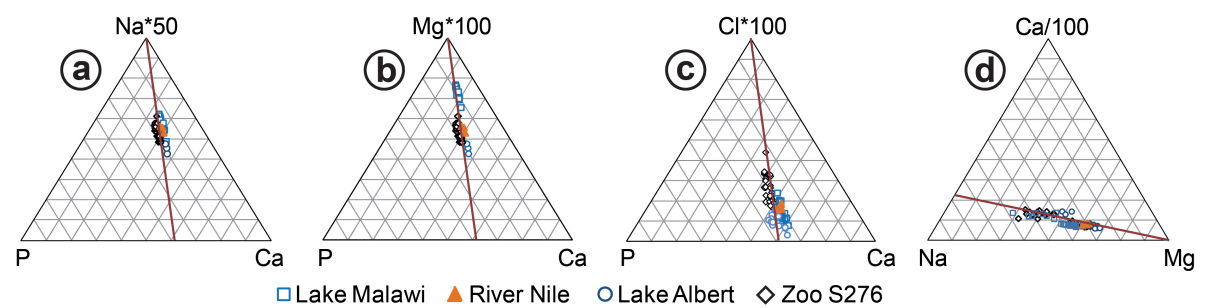

Fossil Dentin \& Cement
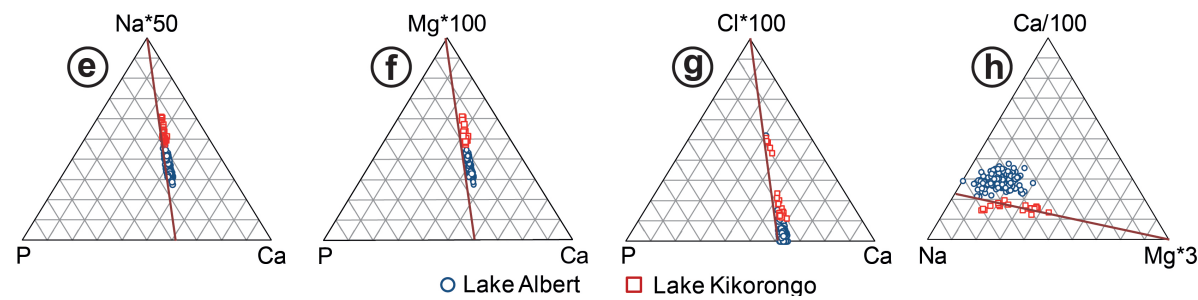

Fig. 6. Triangular diagram of chemical components (atomic proportions) in dentin and cement of modern and fossil Hippopotamid molar teeth. Dashed line defines trend of constant P/Ca ratio observed in modern enamel. (a-d): distribution of $\mathrm{Na} * 50-\mathrm{Ca}-\mathrm{P}, \mathrm{MgO} * 100-\mathrm{Ca}-\mathrm{P}$, $\mathrm{Cl} * 100-\mathrm{Ca}-\mathrm{P}, \mathrm{Ca} / 100-\mathrm{Mg} * 3-\mathrm{Na}$ respectively, in modern dentin and cement (e-h): distribution of $\mathrm{Na} * 50-\mathrm{Ca}-\mathrm{P}, \mathrm{MgO} * 100-\mathrm{Ca}-\mathrm{P}, \mathrm{Cl} * 100-\mathrm{Ca}-$ $\mathrm{P}, \mathrm{Ca} / 100-\mathrm{Mg} * 3-\mathrm{Na}$, respectively, in fossil dentin and cement.
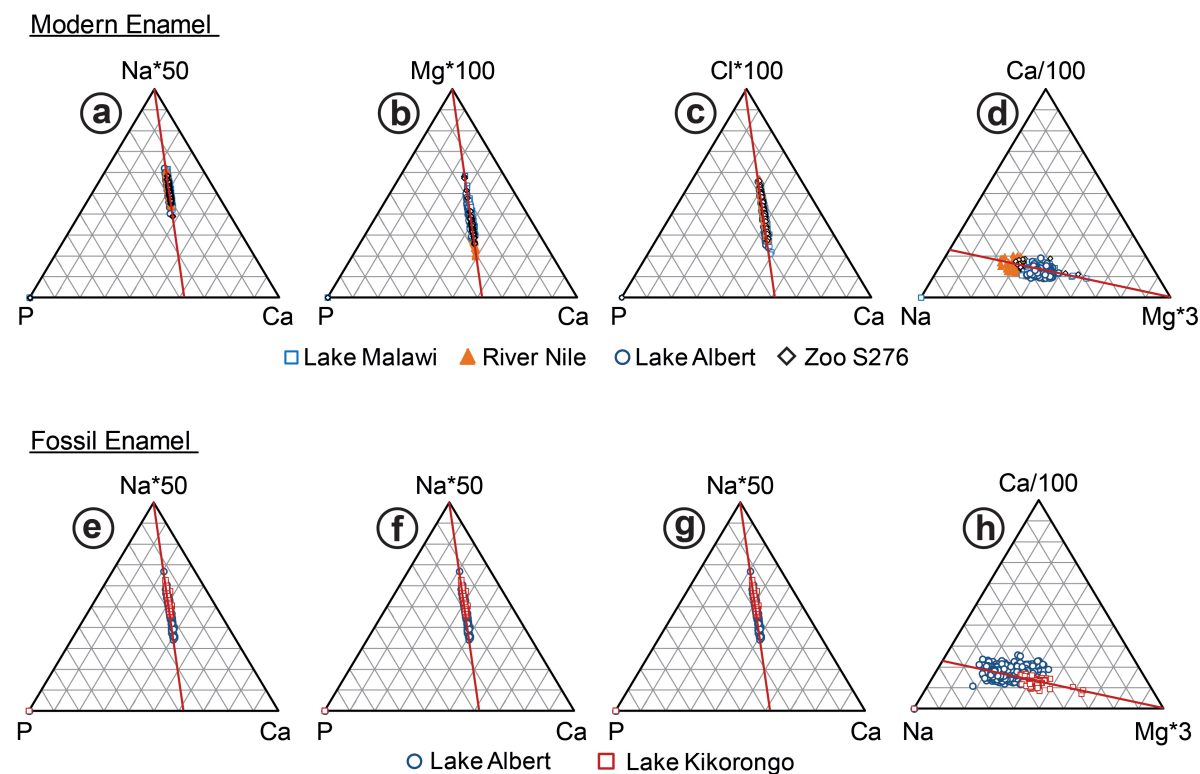

Fig. 7. Triangular diagram of chemical components (atomic proportions) in enamel of modern and fossil Hippopotamid molar teeth. Red line defines trend of constant $\mathrm{P} / \mathrm{Ca}$ ratio observed in modern enamel. Modern and fossil enamel have identical $\mathrm{P} / \mathrm{Ca}$ and display similar variations in $\mathrm{Na}, \mathrm{Mg}, \mathrm{Cl}$, but variable $\mathrm{Mg} / \mathrm{Ca}$ and $\mathrm{Na} / \mathrm{Mg}$. (a-d): distribution of $\mathrm{Na} * 50-\mathrm{Ca}-\mathrm{P}, \mathrm{MgO} * 100-\mathrm{Ca}-\mathrm{P}, \mathrm{Cl} * 100-\mathrm{Ca}-\mathrm{P}, \mathrm{Ca} / 100-\mathrm{Mg} * 3-$ $\mathrm{Na}$ respectively, in modern enamel (e-h): distribution of $\mathrm{Na} * 50-\mathrm{Ca}-\mathrm{P}, \mathrm{MgO} * 100-\mathrm{Ca}-\mathrm{P}, \mathrm{Cl} * 100-\mathrm{Ca}-\mathrm{P}, \mathrm{Ca} / 100-\mathrm{Mg} * 3-\mathrm{Na}$, respectively, in fossil enamel.

6) imply a tight physiological control of the concentration of these elements. Overall, the $\mathrm{Na} / \mathrm{Ca}$ ratio appears to be the least variable, because fossil and modern enamel follow equal trends of constant $\mathrm{Na} / \mathrm{Ca}$ (Fig. 7d, h). Biological extracellular fluids, such as blood plasma and enamel fluid, are in essence $\mathrm{NaCl}$ solutions (Aoba and Moreno, 1987; Larsson et al., 1988; Simmer and Fincham, 1995; Fraústo da Silva and Williams, 2001) and may render compositional changes induced by food intake unlikely. However, ANOVA and the Scheffé tests suggest the $\mathrm{Na}_{2} \mathrm{O}$ variation in the population of 
fossil enamel from Lake Albert to be distinct from those of Lake Kikorongo and modern environments (Table 5). This distinction reflects the low $\mathrm{Na}_{2} \mathrm{O}$ content in fossil enamel from Lake Albert (Table 4). The Scheffé tests also indicate a significant difference between $\mathrm{Cl}$ contents in modern and fossil enamel (Table 5) and this is likely due to the low $\mathrm{Cl}$ contents in fossil enamel relative to modern enamel (Table 4). It is not apparent whether these population differences in $\mathrm{Na}_{2} \mathrm{O}$ and $\mathrm{Cl}$ represent a primary feature induced by a diverse diet or by vital effects. However, it should not be related to loss of $\mathrm{Na}_{2} \mathrm{O}$ and $\mathrm{Cl}$ during alteration. The distributions of these two elements are highly regular in all teeth; this would not be expected, considering the different geological ages and environmental settings, if these elements became mobilized during alteration processes.

The larger variation of $\mathrm{MgO}\left(R^{2}=0.58\right)$ along the regression lines, and the variable $\mathrm{MgO} / \mathrm{Na}_{2} \mathrm{O}$ ratios in enamel from different teeth suggest less physiologically control than in the Na-Cl system (Fig. 7; Table 4). Indeed, enamel from single locations has rather well defined $\mathrm{MgO} / \mathrm{Na}_{2} \mathrm{O}$ ratios but there are differences which potentially enable to distinguish sample provenance from different sites. ANOVA corroborates and the Scheffé test confirms the distinct $\mathrm{MgO}$ distribution among the different enamel populations (Table 5). The fossil specimens are from two different environments: the saline Lake Kikorongo which is of volcanic origin (Bahati et al., 2005) and the Neogene freshwater equivalent to Lake Albert (Lake Obweruka) (Van Damme and Pickford, 2003; Brachert et al., 2010). Compared to the fresh water lakes saline waters are characterized by their high concentrations of $\mathrm{Na}$ and $\mathrm{Cl}$ but also of $\mathrm{Sr}$ and $\mathrm{MgO}$ (Hammer, 1986). Enamel from the tooth of the Kikorongo specimen has distinctively higher $\mathrm{SrO}$ and $\mathrm{MgO}$ concentration than the Lake Albert samples (Figs. 4, 7; Tables 1, 5). In particular the relative proportion of $\mathrm{Na}-\mathrm{Mg}-\mathrm{Ca}$ or the $\mathrm{MgO} / \mathrm{Na}_{2} \mathrm{O}$ ratio can readily distinguish these two environments (Fig. 7h). Thus, the concentrations of these elements in enamel have the potential to be used as proxies distinguishing saline lake from fresh water lake environments. It is interesting to note that the $\mathrm{MgO} / \mathrm{CaO}$ ratio increases in fresh water lakes if prolonged evaporation causes the precipitation of calcite (Yu et al., 2002; Crausbay et al., 2006). Similarly, pedogenic carbonate (calcite) forms in dry climates possibly increasing the $\mathrm{MgO} / \mathrm{CaO}$ ratio in fluids available to plant roots.

The compositions of enamel from animals which lived in the modern, large freshwater lakes (Lake Albert, Lake Malawi) are overlapping (Fig. 8). In fact, no significant difference should be present in enamel from Hippopotamids from these two lakes, when their similar lake character, the similar climate and their similar bed rock assemblage is taken into account. There is no systematic variation with age in the $\mathrm{MgO} / \mathrm{Na}_{2} \mathrm{O}$ ratio in fossil enamel from Lake Albert suggesting that the lake water did not experience major compositional changes between 7 and $1.5 \mathrm{Ma}$. This is supported by the sediment record which is dominated by clastic, arenitic
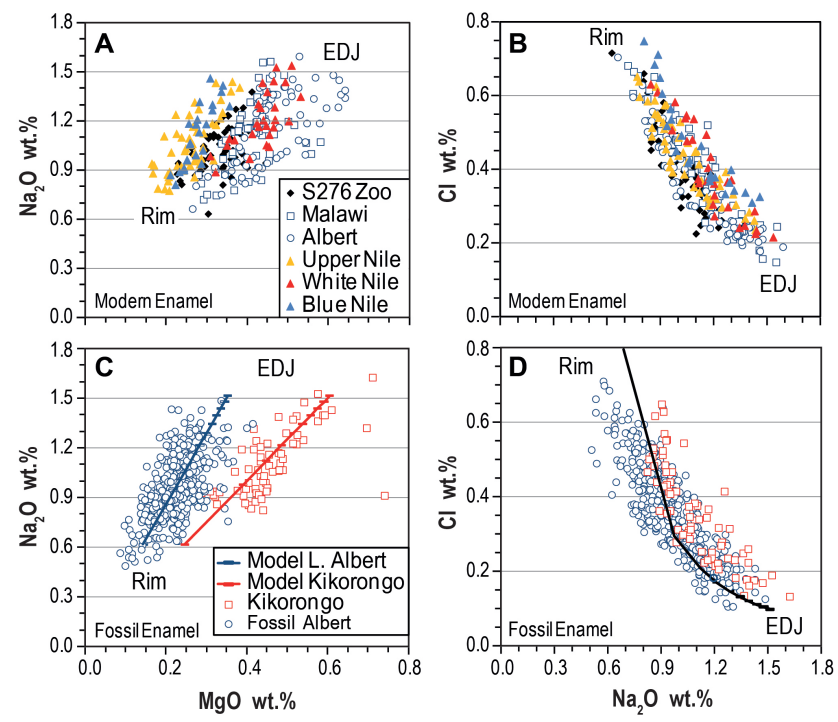

Fig. 8. Variation of $\mathrm{MgO}, \mathrm{Na}_{2} \mathrm{O}$, and $\mathrm{Cl}$ in modern and fossil enamel from Hippopotamid molar teeth. Note the coherent variation of $\mathrm{Cl}$ and $\mathrm{Na}_{2} \mathrm{O}$ in fossil and modern enamel but distinct $\mathrm{MgO}$ contents in enamel from different environments. Blue and red lines represent model calculation assuming fractional crystallization of apatite. For more details see text and Table 6. (a) and (c): $\mathrm{MgO}$ versus $\mathrm{Na}_{2} \mathrm{O}$ variation in enamel of modern and fossil molar teeth (b) and (d): $\mathrm{Na}_{2} \mathrm{O}$ versus $\mathrm{Cl}$ variation in enamel of modern and fossil molar teeth.

to pelitic sediments without any significant amounts of carbonate and only minor limestone beds (Pickford et al., 1993). However, oxygen stable isotope data indicate a trend of continuous evaporation of the lake without precipitating carbonate from about 7 to $2 \mathrm{Ma}$ and carbon isotopes indicate a vegetation change from $\mathrm{C} 3$ to $\mathrm{C} 4$ plants somewhere between 4 and $2 \mathrm{Ma}$ (Brachert et al., 2010). Obviously, the stable isotope systems are more sensitive to evaporation than $\mathrm{MgO} / \mathrm{CaO}$ ratios.

Modern enamel from Hippopotamids living in the Upper and Blue Nile Rivers have systematically lower $\mathrm{Mg} / \mathrm{Na}$ ratios than the modern specimens from the White Nile River, Lake Albert, Lake Malawi, or from the zoo (Figs. 7d, 8). Even enamel from Hippopotamids living in different parts of the river Nile system can be distinguished because the $\mathrm{MgO} / \mathrm{Na}_{2} \mathrm{O}$ and the $\mathrm{MgO} / \mathrm{CaO}$ ratios in White Nile enamel is higher than that from the Blue Nile and Upper Nile (Table 1; Figs. 7, 8). It is well established that the chemical and isotope composition of the water and the sediment load in the Blue Nile and White Nile Rivers differ significantly reflecting the geologically different catchment areas in volcanic rocks dominating the Ethiopian Highland and the Precambrian basement in Uganda, respectively (Palmer and Edmond, 1989; Kempe, 1993; Talbot et al., 2000; Scrivner et al., 2004; Revel et al., 2010). In addition, the White Nile River suffers from strong evaporation and passes 
several swampy and saline areas (Sudd, Nuba and Gezira zone) before joining the Blue Nile River (Salama and Selley, 1997).This could explain the higher $\mathrm{MgO}$ contents and $\mathrm{MgO} / \mathrm{Na}_{2} \mathrm{O}$ ratios in enamel from the White Nile (Fig. 7). Enamel from Blue Nile and Upper Nile show similar $\mathrm{MgO}$ variations (Fig. 7). This probably reflects the dominant contribution of the Blue Nile to the main Nile, with regard to the amount of water flow and sediment load (Foucault and Stanley, 1989; Williams, 2009). Therefore, the two branches of the Nile River system and the shallow and deep lakes, respectively, define distinct settings which exert a strong imprint on chemical signatures of Hippopotamid enamel via nutritional uptake (food and drinking water).

\subsubsection{Implications for the formation of enamel apatite}

Previous studies mainly performed on human, rat or porcupine teeth have established that enamel formation is the result of coordinated extracellular processes involving organic matrix molecules and inorganic ion fluxes that regulate the nucleation and growth of developing apatite crystals (Simmer et al., 2010). During the initial secretory stage of enamel formation, ameloblasts form a protein matrix which modulates the crystallization of long thin ribbons of enamel crystals until the full enamel size is reached (Smith, 1998; Margolis et al., 2006; Simmer et al., 2010). Subsequently, during the maturation stage, these crystals grow in thickness and width maintaining the structural organization of the enamel established during the secretory stage (Robinson et al., 1995). This phase is accompanied by the almost complete removal of proteins and pore fluid, becoming replaced by bioapatite. Thus amelogenesis occurs in a confined space separated from the interstitial body fluid by an epithelium of ameloblasts, which control the in- and outflow of organic and inorganic molecules and ions at each step of enamel formation (Smith, 1998; Hubbard, 2000). Even the regressing epithelium layer during maturation keeps the maturing enamel isolated from the surrounding connective tissue (Smith and Nanci, 1995). Tooth development is finalized at the time of its eruption.

The regular distribution patterns of the main components observed in Hippopotamid enamel appear to be typical for mammal enamel in general, as indicated by studies of rodents, porcupines, apes or hominoids (Besic et al., 1969; Johnson, 1972 Shaw and Yen, 1972; Verbeeck et al., 1985; Driessens et al., 1990). Thus, although the temporal progression of the different stages of amelogenesis and the ultrastructure of the biominerals differs among species (Smith, 2008), the similar element distribution suggests similar control mechanisms during enamel formation. Secretion and maturation of the enamel mineral control the element distribution in the same way in all taxa, and those processes fractionate the elements to different degrees. The distribution patterns of the minor elements in enamel cannot reflect variations in the diet because these different taxa live in very different habitats and have very different food requirements which render it rather implausible that their diet changes in a similar way during the time of tooth formation.

The functions of an element at the cellular or physiological level involve reactions among minerals and inorganic or organic species in the fluid phase and ultimately are attributable to interactions at the molecular level. However, the way the fluxes of the different ions, in particular those of $\mathrm{Na}, \mathrm{Mg}$ and $\mathrm{Cl}$, are physiologically organized across the ameloblast layer is not well known. In healthy animals, large concentration variations of $\mathrm{CaO}$ and $\mathrm{P}_{2} \mathrm{O}_{5}$ in the enamel fluid will not occur at any stage of enamel formation, because these components are stoichiometrically controlled and minor changes in fluid composition alter supersaturating conditions and might trigger the precipitation of different apatite phases (Aoba and Moreno, 1992). The epithelial $\mathrm{Ca}$ transport in and out of the mineralizing zone has been reviewed by Hubbard (2000) and Bawden (1989). Calcium is transported through the ameloblast layer either actively through the ameloblast cell (transcellular) or passively through the junctional complexes between ameloblast cells (paracellular). The first transport mode appears to dominate during the secretion phase and provides a controlled low $\mathrm{Ca}$ flux which maintains a stable environment for appositional growth and the formation of apatite crystallites in the organic matrix until the final size of the enamel body is reached. During this stage the enamel fluid has much lower $\mathrm{Ca}, \mathrm{Mg}$ and $\mathrm{Na}$ concentrations than the interstitial fluid (Aoba and Moreno, 1987; Moreno and Aoba, 1987). However, during the secretion stage concentration and distribution patterns from the EDJ towards the outer enamel of $\mathrm{Na}, \mathrm{Mg}$ and $\mathrm{Cl}$ vary significantly (Sabel et al., 2009).

At the end of appositional growth and the beginning of the maturation phase the rate of apatite formation increases which suggests a much higher Ca flux during the maturation process, possibly 4 times higher than in the secretory phase (Smith, 1998). At this stage also concentrations of $\mathrm{Na}$, and $\mathrm{Mg}$ in enamel appear to be highest (Robinson et al., 1995; Sabel et al., 2009). If maturation begins at the EDJ this explains that enamel near the EDJ has the highest concentrations of these elements. During maturation the ameloblast layer undergoes systematic, periodical morphological changes which modulate the ion transport through paracellular and transcellular pathways. Although these processes are not well understood for the different elements, the systematic decrease in $\mathrm{Mg}$ and $\mathrm{Na}$ in enamel towards the rim implies that there is a decrease of these elements in the maturation fluid with time.

The composition of the enamel fluid filling this space is different from the external fluid and at the various stages of amelogenesis the fluid composition during secretion and maturation is changing but appears to remain in equilibrium with the crystallizing mineral (Aoba and Moreno, 1992; Aoba, 1997; Smith, 1998; Hubbard, 2000). This implies that the composition of the final, mature enamel apatite represents a mixture of at least 2 components: the apatite produced 
during secretion plus that added during maturation. This is supported by the distribution pattern of the minor elements $\mathrm{Na}_{2} \mathrm{O}, \mathrm{MgO}$ and $\mathrm{Cl}$. There is a common trend for $\mathrm{Na}_{2} \mathrm{O}$ and $\mathrm{Cl}$, but $\mathrm{MgO}$ and $\mathrm{Na}_{2} \mathrm{O}$ contents display a fan shaped distribution (Fig. 8). The samples near the EDJ show a broad $\mathrm{MgO}$ variation which becomes smaller towards the outer enamel rim and lower $\mathrm{MgO}$ and $\mathrm{Na}_{2} \mathrm{O}$ concentrations (Fig. 8). In fact, the different populations follow linear trends of rather constant $\mathrm{MgO} / \mathrm{Na}_{2} \mathrm{O}$ ratios passing closely the zero point of the diagram. Hence, the $\mathrm{MgO} / \mathrm{Na}_{2} \mathrm{O}$ ratio in enamel is well preserved during maturation and the concentrations of $\mathrm{Na}_{2} \mathrm{O}$ and $\mathrm{MgO}$ follow in a first approximation a binary mixing trend having secretion and maturation fluids as end members. In other words, the flux of $\mathrm{Na}$ and $\mathrm{Mg}$ ions during maturation through the epithelium is very restricted and is overwhelmed by the flux of major components, such as $\mathrm{Ca}$ and $\mathrm{P}$ and possibly other anions and result in the crystallization of $\mathrm{Mg}$ and Na-poor apatite. The distribution of $\mathrm{Cl}$ and $\mathrm{Na}$ in all enamel specimens shows one linear trend also resembling binary mixing (Fig. 8). But the higher $\mathrm{Cl}$ concentration in the marginal enamel relative to that near the EDJ suggests that $\mathrm{Cl}$ increases in the fluid during maturation.

We do not dismiss the existence of at least two different fluid compositions during enamel amelogenesis including the maturation stage. On the other hand, the observed distribution of $\mathrm{Mg}, \mathrm{Na}$ and $\mathrm{Cl}$ in enamel cannot be explained by simple mixing processes but is ultimately the consequence of the mechanism of apatite crystallization during maturation, i.e. the partitioning behavior of these elements between apatite and fluid $\left(D_{\mathrm{Ap} / \mathrm{Fl}}\right)$. This is because the enamel body is built during appositional growth and it may only consist of about $14 \mathrm{wt}$ \% of apatite before maturation starts (Smith, 1998). If the enamel formed during secretion is homogeneous in composition and ion fluxes of $\mathrm{Na}$ and $\mathrm{Mg}$ into the mineralizing compartment are minimized, the subsequent maturation process must include both, formation of new apatite and re-equilibration of apatite precipitated during tooth secretion. In order to explain the observed element distribution, $\mathrm{Na}, \mathrm{Mg}$ and $\mathrm{Cl}$ initially deposited during secretion have to be redistributed within the enamel body.

\section{Modeling minor element composition of bioapatite}

Both, $\mathrm{Na}$ and $\mathrm{Mg}$ can replace $\mathrm{Ca}$ by ion exchange on the crystal surface and initially during the secretion these elements may occur in a labile status, probably adsorbed onto the crystal surfaces (Aoba et al., 1992a,b). However, in order to remove these elements from the fluid they have to be incorporated into the lattice during crystal growth. This effectively means both elements can be accommodated by hydroxyapatite $\left(D_{\mathrm{Ap} / \mathrm{Fl}}<1\right)$ and they have similar partition coefficients as indicated by the rather constant $\mathrm{MgO} / \mathrm{Na}_{2} \mathrm{O}$ ratio in single teeth and individual populations (Figs. 7, 8). In contrast, $\mathrm{Cl}$ does not fit well into the hydroxyapatite lattice and becomes highly concentrated in the fluid because the pore space decreases to less than $1 \%$. In this case, assuming a constant and low partition coefficient between apatite and fluid $\left(D_{\mathrm{Ap} / \mathrm{Fl}}<1\right)$, the $\mathrm{Cl}$ concentration in apatite must increase with crystallization. The process described above can potentially be quantitatively described by a model assuming equilibrium or fractional crystallization. In this case, equilibrium crystallization presumes that the pores within the enamel body are connected and concentration gradients in the enamel fluid can be compensated by diffusion. This scenario applies to the beginning of the maturation process in order to allow the redistribution of $\mathrm{Na}, \mathrm{Mg}$ and $\mathrm{Cl}$ all over the enamel body. With increasing rate of apatite crystallization, the enamel fluid becomes depleted in $\mathrm{Mg}$ and $\mathrm{Na}$ but enriched in $\mathrm{Cl}$. As the pore spaces are filled with apatite, the enamel body becomes less permeable. In this case fractional crystallization represents an appropriate model to describe the evolution of fluid and apatite composition until it is completely crystallized.

Figure 8c and d show models of Rayleigh (fractional) crystallization (Shaw, 1970) for $\mathrm{Na}_{2} \mathrm{O}, \mathrm{MgO}$ and $\mathrm{Cl}$ variations in enamel from fossil Lake Albert and Lake Kikorongo. Important parameters such as fluid compositions $\left(\mathrm{C}_{\text {Fluid }}\right)$ and apatite-fluid partition coefficients $\left(D_{\mathrm{Ap} / \mathrm{F}}\right)$ are not known. However, this example demonstrates in principle that the proposed process of enamel crystallization can explain the variation of the minor elements in enamel. The calculations are summarized in Table 6 using equations 1 and 2 to calculate the changes in concentration in the residual fluid $\left(C_{\mathrm{F}}\right)$ and solid phase $\left(C_{\mathrm{Ap}}\right)$, respectively.

In a first step the fluid composition during the secretion process is calculated and this is followed by a simulation of the maturation process by letting the fluid crystallize almost to completeness ( $99 \% ; \mathrm{F}=0.01$, Table 6 ). The simplest case is to consider the apatite composition near the EDJ as representative for the apatite crystallizing at the end of secretion $\left(C_{\text {Apatite }}\right.$ in Table 6; Fig. 8). Assuming $D_{\mathrm{Ap} / \mathrm{F}}$ of 1.2 , 1.2 , and 0.5 for $\mathrm{Na}_{2} \mathrm{O}, \mathrm{MgO}$ and $\mathrm{Cl}$, respectively, and that at that time $14 \mathrm{wt} . \quad \%(F=0.86$; Smith, 1998) of enamel have crystallized. In this case the initial composition of the secretion fluids from Lake Albert and Lake Kikorongo have different $\mathrm{MgO}$ contents $(0.3$ wt. \%, 0.52 wt. \%, respectively; Table 6) but similar $\mathrm{Na}_{2} \mathrm{O}$ and $\mathrm{Cl}$ contents ( 1.29 wt. $\% \mathrm{Na}_{2} \mathrm{O}$, 0.19 wt. \% Cl; Table 6). The change in apatite compositions as the fluid crystallizes follows closely the trend observed in our samples and the apatite composition at the end of crystallization is very similar to that observed at the outer rim of the enamel from Lake Albert and Lake Kikorongo (Table 6, Fig. 8). Models of equilibrium crystallization give similar compositional trends, although partition coefficients for $\mathrm{Na}_{2} \mathrm{O}$ and $\mathrm{MgO}$ will be higher $(\sim 3)$ and for $\mathrm{Cl}$ lower (ca. 0.1 ). One could also consider continued addition of fluid and minor amounts of $\mathrm{Cl}, \mathrm{Mg}$, and $\mathrm{Na}$ into the mineralizing compartment using models describing the concomitant crystallization and replenishment (O'Hara and Mathews, 1981). However, at this stage fine-tuning of the models provides no 
Table 6. Rayleigh crystallization model for enamel formation.

\begin{tabular}{|c|c|c|c|c|c|c|c|}
\hline & $* \mathrm{~F}$ & $\mathrm{Na}_{2} \mathrm{O}$ & $\mathrm{MgO}$ & $\mathrm{Cl}$ & $\mathrm{Na}_{2} \mathrm{O}$ & $\mathrm{MgO}$ & $\mathrm{Cl}$ \\
\hline & & \multicolumn{3}{|c|}{ Lake Kikorongo } & \multicolumn{3}{|c|}{ Fossil Lake Albert } \\
\hline \multicolumn{8}{|c|}{ Calculation of fluid composition at the end of secretion stage } \\
\hline$* * D_{\mathrm{Ap} / \mathrm{Fl}}$ & & 1.2 & 1.2 & 0.5 & 1.2 & 1.2 & 0.5 \\
\hline$* * * C_{\text {Apatite }}$ wt. $\%$ & & 1.5 & 0.6 & 0.1 & 1.5 & 0.35 & 0.1 \\
\hline$C_{\text {Fluid wt. } \%}$ & 0.86 & 1.29 & 0.52 & 0.19 & 1.29 & 0.30 & 0.19 \\
\hline \multicolumn{8}{|c|}{ Calculation of apatite composition during maturation } \\
\hline \multirow[t]{11}{*}{$C_{\text {Apatite wt. } \%}$} & 0.9 & 1.51 & 0.61 & 0.10 & 1.51 & 0.35 & 0.10 \\
\hline & 0.8 & 1.48 & 0.59 & 0.10 & 1.35 & 0.31 & 0.13 \\
\hline & 0.7 & 1.44 & 0.58 & 0.11 & 1.22 & 0.28 & 0.17 \\
\hline & 0.6 & 1.40 & 0.56 & 0.12 & 0.98 & 0.23 & 0.29 \\
\hline & 0.5 & 1.35 & 0.54 & 0.13 & 0.85 & 0.20 & 0.41 \\
\hline & 0.4 & 1.29 & 0.51 & 0.15 & 0.62 & 0.14 & 0.93 \\
\hline & 0.3 & 1.22 & 0.49 & 0.17 & 0.54 & 0.13 & 1.31 \\
\hline & 0.2 & 1.12 & 0.45 & 0.21 & 1.12 & 0.26 & 0.21 \\
\hline & 0.1 & 0.98 & 0.39 & 0.29 & 0.98 & 0.23 & 0.29 \\
\hline & 0.05 & 0.85 & 0.34 & 0.41 & 0.85 & 0.20 & 0.41 \\
\hline & 0.01 & 0.62 & 0.25 & 0.93 & 0.62 & 0.14 & 0.93 \\
\hline
\end{tabular}

$* \mathrm{~F}$ : fraction of fluid remaining;

** D:partition coefficient apatite/fluid;

$* * *$ C: concentration (wt. \%) of fluid or apatite.

additional information, because important parameters such as fluid composition, ratio of fluid addition to amount of crystallization or the partition coefficient between apatite and fluid are not known.

The model described above implies that the maturation process is the dominant process controlling the element distribution in enamel. This is likely, because the main mass of enamel apatite crystallizes during this phase of tooth evolution (ca. 86 wt.\%; Smith, 1998). In detail, the spatial and temporal progression of the maturation within the enamel body is not known. However, the $\mathrm{MgO}, \mathrm{Na}_{2} \mathrm{O}$ and $\mathrm{Cl}$ concentration along longitudinal sections near the EDJ are high and rather constant and therefore do not display the typical distribution observed perpendicular to the EDJ (see data for samples Alb10-L1, Mal8-L1, S-276-L1, 5306-L1 in Tables S1 and S3 in the Supplement). This suggests maturation involves the entire tooth but equilibration and addition of new apatite starts at the EDJ. The proposed crystallization mechanisms might entail the composition of the enamel near the EDJ to be not representative for the secretion phase. However, because partition coefficients should be similar at all stages of apatite formation, $\mathrm{MgO} / \mathrm{Na}_{2} \mathrm{O}$ ratios in the initial apatite should be similar to that observed at the EDJ, and therefore our conclusions regarding the potential of this ratio to distinguish environmental settings are upholding. Future detailed micro analysis with spatial resolution distinguishing growth features such as the Retzius lines and maturation fronts may quantitatively resolve the different contributions of secretion and maturation processes on the element distribution in enamel.

\section{Conclusions}

This study is aimed to provide a detailed data base on major and minor element compositions of modern and fossil teeth from Hippopotamids in order to (1) identify sedimentary environments, (2) asses chemical distribution patterns induced during enamel formation and (3) to recognize diagenetic overprint.

Secondary alteration controls in particular $\mathrm{FeO}, \mathrm{MnO}$, $\mathrm{SO}_{3}$ and $\mathrm{F}$ concentrations, which are 2 to 10 times higher in fossil than in modern enamel. The post-mortem addition of these elements appears to be a general phenomenon in fossil bone and tooth materials, irrespective of age and the environmental settings. Very often the distribution of these elements along enamel profiles perpendicular to the EDJ shows U-shape patterns which are the result of diffusive migration of the surrounding pore solution in the sediment into the tooth (Millard and Hedges, 1996; Kohn, 2008). The addition of $\mathrm{F}, \mathrm{FeO}, \mathrm{MnO}$, and $\mathrm{SO}_{3}$ occurs at constant $\mathrm{Ca} / \mathrm{P}$ ratios, which implies that secondary $\mathrm{Ca}-\mathrm{P}$ minerals, such as fluorite or vivianite, do not precipitate during alteration. The concentrations of components such as $\mathrm{SiO}_{2}, \mathrm{Al}_{2} \mathrm{O}_{3}, \mathrm{~K}_{2} \mathrm{O}$ are often low $(<0.1 \mathrm{wt} . \%)$ in fossil and modern material indicating mechanical introduction and precipitation of silicate minerals has not been relevant. Fossil dentin and cement 
have lower $\mathrm{P}_{2} \mathrm{O}_{5}$ and $\mathrm{CaO}$ contents than enamel and even the $\mathrm{Ca} / \mathrm{P}$ ratio differs from that enamel. However, because of the large variation of the concentrations, including those of $\mathrm{Na}, \mathrm{Mg}$ and $\mathrm{Cl}$, no systematic difference between fossil and modern dentin and cement can be identified. Systematic studies along dentin growth structures have to be made in order to evaluate whether the observed chemical distributions represent original patterns manifested during dentin and cement formation or whether they have been overprinted by post-mortem processes.

Throughout modern and fossil enamel bodies $\mathrm{P}_{2} \mathrm{O}_{5}$ and $\mathrm{CaO}$ contents and the $\mathrm{CaO} / \mathrm{P}_{2} \mathrm{O}_{5}$ ratio are very constant and do not display systematic trends along sections perpendicular to the EDJ or along cervix-apex profiles. Linear regression analysis reveals very tight control on the variation of $\mathrm{MgO}$, $\mathrm{Na}_{2} \mathrm{O}$ and $\mathrm{Cl}\left(R^{2}=0.64\right.$ to 0.95$)$ despite large concentration variations across the enamel and regardless of their age and origin. The concentration of $\mathrm{MgO}$ and $\mathrm{Na}_{2} \mathrm{O}$ decrease from the EDJ towards the outer rim, whereas $\mathrm{Cl}$ displays the opposite variation. As a result, ratios such as $\mathrm{MgO} / \mathrm{CaO}$, $\mathrm{Na}_{2} \mathrm{O} / \mathrm{CaO}$ or $\mathrm{Cl} / \mathrm{CaO}$ also systematically decrease or increase towards the enamel rim and are interpreted to reflect changes in the apatite composition rather than changes in mineral density. Similar distribution pattern have been observed in enamel from other mammals like rats, porcupines, apes and humans, which implies that the variation of these elements in enamel apatite is well physiologically controlled and that the fundamental chemical processes of mineralization during amelogenesis follow predominantly the same laws.

During the secretion and maturation phases of amelogenesis the epithelium generates different fluid compositions and, in principle, the final composition of enamel apatite is controlled by two fluid compositions. This is supported by co-linear relationships between $\mathrm{MgO}, \mathrm{Cl}$ and $\mathrm{Na}_{2} \mathrm{O}$ which can be interpreted to represent binary mixing lines. A plausible explanation for the observed minor element distribution is that both, apatite crystallites precipitating during secretion and apatite crystallizing during maturation equilibrate with a continuously evolving fluid and bioapatite eventually replaces organic matrices and the enamel fluid. This process might be described by equilibrium and fractional crystallization models with continuous replenishment of the mineralizing chamber with maturation fluid.

Despite the opposite behavior of $\mathrm{Cl}$ and $\mathrm{Na}_{2} \mathrm{O}$ the variation is co-linear in all specimens and overall differences among enamel from different environments are difficult to resolve. However, $\mathrm{MgO}$ concentrations and $\mathrm{MgO} / \mathrm{Na}_{2} \mathrm{O}$ ratios in enamel are different among various environments. In particular in river and lake water environments, which have been effected by strong evaporation (saline environments), enamel has high $\mathrm{MgO}$ concentrations and $\mathrm{MgO} / \mathrm{CaO}$ ratios if compared with their fresh water counterparts. The $\mathrm{MgO} / \mathrm{Na}_{2} \mathrm{O}$ ratio in single specimens is rather constant and this makes this ratio a sensitive fingerprint of certain environments.
The proposed process of apatite crystallization during enamel formation, despite representing an oversimplification, poses some questions upon the meaning of other proxies regarding environmental changes and regarding sampling strategies. For example, the oxygen isotope composition is a very sensitive signal of environmental change (temperature, precipitation or aridity), which is effectively transferred into the animal's body fluid. How does the oxygen isotope composition in the different enamel fluids vary during secretion and maturation? If enamel apatite crystallizes in equilibrium with the surrounding, but continuously evolving fluid, how does the oxygen isotope composition at a specific location in the enamel body change with time and which time frame does it represent? Which time frames do we analyze if serial sampling follows transects parallel to or perpendicular to the EDJ? The answers to these questions are important in order to recover meaningful short time-scale information from the incremental growth structures of bioapatite.

\section{Supplementary material related to this article is available online at: http://www.biogeosciences.net/9/119/2012/ bg-9-119-2012-supplement.zip.}

Acknowledgements. We very much appreciate thorough and helpful reviews by Th. Tütken (University of Bonn) and an anonymous referee. We are grateful for detailed information on nutritional behavior of hippopotamus by F. von Houwald (Zoo of Basel), J. Hummel (University of Bonn) and A. Sliwa (Zoo of Cologne). We thank our Ugandan research partners (Makerere University, Kampala) for their support as well as A. Schumann (Kampala) for his help with logistics. K.-H. Becker, M. Maus and A. Budsky (University of Mainz) and M. Biegler (Max Planck Insitute for Chemistry, Mainz) prepared thin sections and mini core samples, N. Groschopf (University of Mainz) helped during microprobe analyses. We also thank W. Kießling (Museum of Natural History, Berlin) for efficient editorial handling. Funding by the German Research Foundation (DFG, Research Unit RIFTLINK, project $\mathrm{C} 1)$ is gratefully acknowledged.

Edited by: W. Kießling

\section{References}

Anderson, P. E., Benton, M. J., Trueman, C. N., Paterson, B. A., and Cuny, G.: Palaeoenvironments of vertebrates on the southern shore of tethys: The nonmarine early cretaceous of Tunisia, Palaeogeogr. Palaeocl., 243, 118-131, 2007.

Aoba, T.: The effect of fluoride on apatite structure and growth, Critical Reviews in Oral Biology Medicine, 8, 136-153, doi:10.1177/10454411970080020301, 1997.

Aoba, T. and Moreno, E.: The enamel fluid in the early secretory stage of porcine amelogenesis: Chemical composition and saturation with respect to enamel mineral, Calcified Tissue Int., 41, 86-94, doi:10.1007/bf02555250, 1987. 
Aoba, T. and Moreno, E.: Changes in the nature and composition of enamel mineral during procine amelogenesis, Calcified Tissue Int., 47, 356-364, doi:10.1007/bf02555887, 1990.

Aoba, T. and Moreno, E. C.: Changes in the solubility of enamel mineral at various stages of porcine amelogenesis, Calcified Tissue Int., 50, 266-272, doi:10.1007/bf00296292, 1992.

Aoba, T., Moreno, E. C., and Shimoda, S.: Competitive adsorption of magnesium and calcium ions onto synthetic and biological apatites, Calcified Tissue Int., 51, 143-150, doi:10.1007/bf00298503, 1992a.

Aoba, T., Shimoda, S., and Moreno, E. C.: Labile or surface pools of magnesium, sodium, and potassium in developing porcine enamel mineral, J. Dent. Res., 71, 1826-1831, doi:10.1177/00220345920710111201, 1992b.

Bahati, G., Pang, Z., Ármannsson, H., Isabirye, E. M., and Kato, V.: Hydrology and reservoir characteristics of three geothermal systems in western Uganda, Geothermics, 34, 568-591, 2005.

Bawden, J. W.: Calcium transport during mineralization, The Anatomical Record, 224, 226-233, doi:10.1002/ar.1092240212, 1989.

Besic, F. C., Knowles, C. R., Wiemann, M. R., and Keller, O.: Electron probe microanalysis of noncarious enamel and dentin and calcified tissues in mottled teeth, J. Dent. Res., 48, 131-139, doi:10.1177/00220345690480010501, 1969.

Beuning, K. R. M., Talbot, M. R., and Kelts, K.: A revised 30,000year paleoclimatic and paleohydrologic history of Lake Albert, east africa, Palaeogeogr. Palaeocl., 136, 259-279, 1997.

Boisserie, J.-R.: The phylogeny and taxonomy of hippopotamidae (mammalia: Artiodactyla): A review based on morphology and cladistic analysis, Zool. J. Linn. Soc., 143, 1-26, 2005.

Boisserie, J. R., Zazzo, A., Merceron, G., Blondel, U., Vignaud, P., Likius, A., Mackaye, H. T., and Brunet, M.: Diets of modern and late Miocene Hippopotamids: Evidence from carbon isotope composition and micro-wear of tooth enamel, Palaeogeogr. Palaeocl., 221, 153-174, 2005.

Boskey, A. L.: Mineralization of bones and teeth, Elements, 3, 385391, doi:10.2113/gselements.3.6.385, 2007.

Brachert, T., Brügmann, G., Mertz, D., Kullmer, O., Schrenk, F., Jacob, D., Ssemmanda, I., and Taubald, H.: Stable isotope variation in tooth enamel from Neogene Hippopotamids: Monitor of meso and global climate and rift dynamics on the Albertine Rift, Uganda, Int. J. Earth Sci., 99, 1663-1675, doi:10.1007/s00531010-0518-1, 2010.

Buddecke, E.: Biochemische Grundlagen der Zahnmedizin, Walter de Gruyter, Berlin, New York, 192 pp., 1981.

Cerling, T. E., Harris, J. M., MacFadden, B. J., Leakey, M. G., Quade, J., Eisenmann, V. and Ehleringer, J. R.: Global vegetation change through the Miocene-Pliocene boundary, Nature, 389, 153-158, 1997.

Cerling, T. E., Harris, J. M., and Passey, B. H.: Diets of east african bovidae based on stable isotope analysis, J. Mammal., 84, 456-470, doi:10.1644/15451542(2003)084;0456:DOEABB ¿2.0.CO;2, 2003.

Cerling, T. E., Harris, J. M., Hart, J. A., Kaleme, P., Klingel, H., Leakey, M. G., Levin, N. E., Lewison, R. L., and Passey, B. H.: Stable isotope ecology of the common hippopotamus, J. Zool., 276, 204-212, doi:10.1111/j.1469-7998-2008.00450.x, 2008.

Chansa, W., Senzota, R., Chabwela, H., and Nyirenda, V.: The influence of grass biomass production on hippopotamus population density distribution along the luangwa river in zambia, J. Ecol. Natur. Environ., 3, 186-194, 2011.

Copeland, S. R., Sponheimer, M., Lee-Thorp, J. A., le Roux, P. J., de Ruiter, D. J., and Richards, M. P.: Strontium isotope ratios in fossil teeth from South Africa: Assessing laser ablation mc-icpms analysis and the extent of diagenesis, J. Archaeol. Sci., 37, 1437-1446, 2010.

Crausbay, S., Russell, J., and Schnurrenberger, D.: A ca. $800 \mathrm{yr}$ lithologic record of drought from sub-annually laminated lake sediment, East Java, J. Paleolimnol., 35, 641-659, doi:10.1007/s10933-005-4440-7, 2006.

Dauphin, Y. and Williams, C. T.: Diagenetic trends of dental tissues, C. R. Palevol, 3, 583-590, 2004.

Dolphin, A. E. and Goodman, A. H.: Maternal diets, nutritional status, and zinc in contemporary mexican infants' teeth: Implications for reconstructing paleodiets, Am. J. Phys. Anthropol., 140, 399-409, 2009.

Driessens, F. C. M., Goldberg, M., Heijligers, H. J. M., Carreau, J. P., and Verbeeck, R. M. H.: Gradients in the composition of enamel and dentin mineral in rat incisors, B. Soc. Chim. Belg., 99, 861-864, doi:10.1002/bscb.19900991013, 1990.

Fitch, A., Grauer, A., and Augustine, L.: Lead isotope ratios: Tracking the migration of european-americans to grafton, illinois in the 19th century, Int. J. Osteoarchaeol., doi:10.1002/oa.1207, 2010.

Forbes, M. S., Kohn, M. J., Bestland, E. A., and Wells, R. T.: Late Pleistocene environmental change interpreted from $\delta^{13} \mathrm{C}$ and $\delta^{18} \mathrm{O}$ of tooth enamel from the Black Creek Swamp megafauna site, Kangaroo Island, South Australia, Palaeogeogr., Palaeocl., 291, 319-327, 2010.

Foucault, A. and Stanley, D. J.: Late Quaternary palaeoclimatic oscillations in East Africa recorded by heavy minerals in the Nile Delta, Nature, 339, 44-46, 1989.

Fraústo da Silva, J. J. R. and Williams, R. J. P.: The biological chemistry of the elements : The inorganic chemistry of life, Oxford Univ. Press, Oxford, 2001.

Fricke, H. C. and O'Neil, J. R.: Inter- and intra-tooth variation in the oxygen isotope composition of mammalian tooth enamel phosphate: Implications for palaeoclimatological and palaeobiological research, Palaeogeogr., Palaeocl., 126, 91-99, 1996.

Fricke, H. C., Clyde, W. C., O'Neill, J. R., and Gingerich, P. D.: Evidence for rapid climate change in north america during the latest Paleocene thermal maximum: Oxygen isotope compositions of biogenic phosphate from the Bighorn Basin (Wyoming), Earth Planet. Sci. Lett., 160, 193-208, 1998.

Glimcher, M. J., Cohen-Solal, L., Kossiva, D., and de Ricqles, A.: Biochemical analyses of fossil enamel and dentin, Paleobiology, 16, 219-232, 1990.

Glimcher, M. J.: Bone: Nature of the calcium phosphate crystals and cellular, structural, and physical chemical mechanisms in their formation, Reviews in Mineralogy and Geochemistry, 64, 223-282, doi:10.2138/rmg.2006.64.8, 2006.

Grandstaff, D. E., and Terry Jr, D. O.: Rare earth element composition of Paleogene vertebrate fossils from toadstool geologic park, Nebraska, USA, Appl. Geochem., 24, 733-745, 2009.

Hammer, U. T.: Saline lake ecosystems of the world, Monographiae biologicae, 59, Springer, 632 pp., 1986.

Herwartz, D., Tütken, T., Münker, C., Jochum, K. P., Stoll, B., and Sander, P. M.: Timescales and mechanisms of REE and Hf uptake in fossil bones, Geochim. Cosmochim. Acta, 75, 82-105, 
2011.

Hubbard, M. J.: Calcium transport across the dental enamel epithelium, Crit. Rev. Oral Biol. M., 11, 437-466, doi:10.1177/10454411000110040401, 2000.

Jacques, L., Ogle, N., Moussa, I., Kalin, R., Vignaud, P., Brunet, M., and Bocherens, H.: Implications of diagenesis for the isotopic analysis of upper Miocene large mammalian herbivore tooth enamel from Chad, Palaeogeogr., Palaeocl., 266, 200-210, 2008.

Johnson, A. R.: Strontium, calcium, magnesium, and phosphorus content of rat incisors as determined by electron microprobe analysis, J. Dent. Res., 51, 115-121, doi:10.1177/00220345720510010301, 1972.

Kempe, S.: Damming the Nile, Mitt. Geol.-Paläont. Inst. Univ. Hamburg, 74, 81-114, 1993.

Koch, P. L.: Isotopic reconstruction of past continental environments, Annu. Rev. Earth Pl. Sci., 26, 573-613, doi:10.1146/annurev.earth.26.1.573, 1998.

Koch, P. L.: Isotopic study of the biology of modern and fossil vertebrates, in: Stable isotopes in Ecology and Environmental Science, edited by: Michener, R. and Lajtha, K., 2nd Edition, Oxford (Blackwell), 99-154, 2007.

Koch, P. L., Diffenbaugh, N. S., and Hoppe, K. A.: The effects of late quaternary climate and $p \mathrm{CO}_{2}$ change on $\mathrm{C}_{4}$ plant abundance in the South-Central United States, Palaeogeogr. Palaeocl., Palaeoecology, 207, 331-357, 2004.

Kohn, M. J.: Predicting animal $\delta^{18} \mathrm{O}$ : Accounting for diet and physiological adaptation, Geochim. Cosmochim. Acta, 60, 48114829, 1996.

Kohn, M. J.: Models of diffusion-limited uptake of trace elements in fossils and rates of fossilization, Geochim. Cosmochim. Acta, 72, 3758-3770, 2008.

Kohn, M. J. and Cerling, T. E.: Stable isotope compositions of biological apatite, in: Phosphates - geochemical, geobiological, and materials importance, edited by: Kohn, M. J., Rakovan, J., and Hughes, J. M., Reviews in Mineralogy and Geochemistry, Mineralogical Society of America, Washington, DC, 455-488, 2002.

Kohn, M. J., Schoeninger, M. J., and Valley, J. W.: Herbivore tooth oxygen isotope compositions: Effects of diet and physiology, Geochim. Cosmochim. Acta, 60, 3889-3896, 1996.

Kohn, M. J., Schoeninger, M. J., and Barker, W. W.: Altered states: Effects of diagenesis on fossil tooth chemistry, Geochim. Cosmochim. Acta, 63, 2737-2747, 1999.

Larsson, P. A., Howell, D. S., Pita, J. C., and Blanco, L. N.: Aspiration and characterization of predentin fluid in developing rat teeth by means of a micropuncture and micro-analytical technique, J. Dent. Res., 67, 870-875, doi:10.1177/00220345880670051501, 1988.

Longinelli, A.: Oxygen isotopes in mammal bone phosphate: a new tool for palaeoclimatological and palaeoenvironmental research? Geochim. Cosmochim. Acta, 48, 385-390, 1984.

Lundgren, T., Persson, L. G., Engström, E. U., Chabala, J., LeviSetti, R., and Norén, J. G.: A secondary ion mass spectroscopic study of the elemental composition pattern in rat incisor dental enamel during different stages of ameloblast differentiation, Arch. Oral Biol., 43, 841-848, 1998.

MacFadden, B. J., Solounias, N., and Cerling, T. E.: Ancient diets, ecology, and extinction of 5-millionyear-old horses from Florida, Science, 283, 824-827, doi:10.1126/science.283.5403.824, 1999.

Margolis, H. C., Beniash, E., and Fowler, C. E.: Role of macromolecular assembly of enamel matrix proteins in enamel formation, J. Dent. Res., 85, 775-793, doi:10.1177/154405910608500902, 2006.

Millard, A. R. and Hedges, R. E. M.: A diffusion-adsorption model of uranium uptake by archaeological bone, Geochim. Cosmochim. Acta, 60, 2139-2152, 1996.

Moreno, E. C. and Aoba, T.: Calcium binding in enamel fluid and driving force for enamel mineralization in the secretory stage of amelogenesis, Adv. Dent. Res., 1, 245-251, doi:10.1177/08959374870010021301, 1987.

Norén, J. G., Lodding, A., Odelius, H., and Linde, A.: Secondary ion mass spectrometry of human deciduous enamel, Caries Res., 17, 496-502, 1983.

O'Hara, M. J. and Mathews, R. E.: Geochemical evolution in an advancing, periodically replenished, periodically tapped, continuously fractionated magma chamber, J. Geol. Soc., 138, 237-277, doi:10.1144/gsjgs.138.3.0237, 1981.

Palmer, M. R. and Edmond, J. M.: The strontium isotope budget of the modern ocean, Earth Planet. Sci. Lett., 92, 11-26, 1989.

Pasteris, J. D., Wopenka, B., and Valsami-Jones, E.: Bone and tooth mineralization: Why apatite?, Elements, 4, 97-104, doi:10.2113/gselements.4.2.97, 2008.

Patrick, D., Martin, J. E., Parris, D. C., and Grandstaff, D. E.: Paleoenvironmental interpretations of rare earth element signatures in mosasaurs (reptilia) from the Upper Cretaceous Pierre Shale, Central South Dakota, USA, Palaeogeogr., Palaeocl., 212, 277294, 2004.

Pickford, M., Senut, B., and Hadoto, D.: Geology and palaeontology of the Albertine Rift Valley, Uganda-Zaire, Publication Occasionelle, Centre International pour la Formation et les Echanges Geologiques, Orléans Cedex 2, 24, 1-190, 1993.

Pike, A. W. G., Hedges, R. E. M., and Van calsteren, P.: U-series dating of bone using the diffusion-adsorption model, Geochim. Cosmochim. Acta, 66, 4273-4286, 2002.

Revel, M., Ducassou, E., Grousset, F. E., Bernasconi, S. M., Migeon, S., Revillon, S., Mascle, J., Murat, A., Zaragosi, S., and Bosch, D.: $100000 \mathrm{yr}$ of African monsoon variability recorded in sediments of the Nile margin, Quaternary Sci. Rev., 29, 13421362, 2010.

Robinson, C., Kirkham, J., Brookes, S. J., Bonass, W. A., and Shore, R. C.: The chemistry of enamel development, Int. J. Dev. Biol. , 39, 145-115, 1995.

Sabel, N., Klinberg, G., Nietsche, S., Robertson, A., Odelius, H., and Noren, J.: Analysis of some elements in primary enamel during postnatal mineralization, Swed. Dent. J., 33, 85-95, 2009.

Safont, S., Malgosa, A., Subirà, M., and Gibert, J.: Can trace elements in fossils provide information about palaeodiet?, Int. J. Osteoarchaeol., 8, 23-37, doi:10.1002/(sici)10991212(199801/02)8:1¡23::aid-oa403¡3.0.co;2-r, 1998.

Salama, R. B. and Selley, R. C.: Chapter 6 rift basins of the Sudan, in: Sedimentary basins of the world, Elsevier, 105-149, doi:10.1016/S1874-5997(97)80009-3, 1997.

Scrivner, A. E., Vance, D., and Rohling, E. J.: New neodymium isotope data quantify Nile involvement in mediterranean anoxic episodes, Geology, 32, 565-568, doi:10.1130/g20419.1, 2004.

Senut, B. and Pickford, M.: Geology and palaeobiology of the Albertine Rift Valley, Uganda-Zaire. Volume ii: Palaeobiology, in: 
Publication Occasionelle, Centre International pour la Formation et les Echanges Geologiques, Orléans Cedex 2, 1-423, 1994.

Shaw, D. M.: Trace element fractionation during anatexis, Geochim. Cosmochim. Acta, 34, 237-243, 1970.

Shaw, J. H. and Yen, P. K.-J.: Sodium, potassium, and magnesium concentrations in the enamel and dentin of human and rhesus monkey teeth, J. Dent. Res., 51, 95-101, doi:10.1177/00220345720510013701, 1972.

Sillen, A. and Kavanagh, M.: Strontium and paleodietary research: A review, Am. J. Phys. Anthropol., 25, 67-90, 1982.

Sillen, A.: Elemental and isotopic analyses of mammalian fauna from Southern Africa and their implications for paleodietary research, Am. J. Phys. Anthropol., 76, 49-60, 1988.

Simmer, J. P. and Fincham, A. G.: Molecular mechanisms of dental enamel formation, Crit. Rev. Oral Biol. M., 6, 84-108, doi:10.1177/10454411950060020701, 1995.

Simmer, J. P., Papagerakis, P., Smith, C. E., Fisher, D. C., Rountrey, A. N., Zheng, L., and Hu, J. C.-C.: Regulation of dental enamel shape and hardness, J. Dent. Res., 89, 1024-1038, doi:10.1177/0022034510375829, 2010.

Simonetti, A., Buzon, M., and Creaser, R.: In-situ elemental and Sr isotope investigations of human tooth enamel by laser ablation -(MC)-ICP-MS: Successes and pitfalls, Archaeometry, 50, 371$385,2008$.

Smith, C. E.: Cellular and chemical events during enamel maturation, Crit. Rev. Oral Biol. M., 9, 128-161, doi:10.1177/10454411980090020101, 1998.

Smith, T. M.: Incremental dental development: Methods and applications in hominoid evolutionary studies, J. Hum. Evol., 54, 205-224, 2008.

Smith, C. E. and Nanci, A.: Overview of morphological changes in enamel organ cells associated with major events in amelogenesis., Int. J. Dev. Biol., 39, 153-161, 1995.

Sponheimer, M. and Lee-Thorp, J. A.: Enamel diagenesis at South African australopith sites: Implications for paleoecological reconstruction with trace elements, Geochim. Cosmochim. Acta, 70, 1644-1654, 2006.

Sponheimer, M., Lee-Thorp, J. A., DeRuiter, D. J., Smith, J. M., van der Merwe, N. J., Reed, K., Grant, C. C., Ayliffe, L. K., Robinson, T. F., Heidelberger, C., and Marcus, W.: Diets of Southern African bovidae: Stable isotope evidence, J. Mammal., 84, 471-479, doi:10.1644/15451542(2003)084;0471:DOSABS $;$ 2.0.CO;2, 2003.

Steinfort, J., Driessens, F. C. M., Heijligers, H. J. M., and Beertsen, W.: The distribution of magnesium in developing rat incisor dentin, J. Dent. Res., 70, 187-191, doi:10.1177/00220345910700030601, 1991.
Talbot, M. R., Williams, M. A. J., and Adamson, D. A.: Strontium isotope evidence for late Pleistocene reestablishment of an integrated Nile drainage network, Geology, 28, 343-346, doi:10.1130/0091-7613(2000)28;343:sieflp i2.0.co;2, 2000.

Trueman, C. N., Behrensmeyer, A. K., Potts, R., and Tuross, N.: High-resolution records of location and stratigraphic provenance from the rare earth element composition of fossil bones, Geochim. Cosmochim. Acta, 70, 4343-4355, 2006.

Tütken, T., Vennemann, T. W., and Pfretzschner, H. U.: Early diagenesis of bone and tooth apatite in fluvial and marine settings: Constraints from combined oxygen isotope, nitrogen and REE analysis, Palaeogeogr., Palaeocl., 266, 254-268, 2008.

Tütken, T., Vennemann, T. W., and Pfretzschner, H.-U.: Nd and $\mathrm{Sr}$ isotope compositions in modern and fossil bones - proxies for vertebrate provenance and taphonomy. Geochim. Cosmochim. Acta, 75, 5951-7970, doi:10.1016/j.gca.2011.07.024, 2011.

Van Damme, D. and Pickford, M.: The Late Cenozoic thiaridae (mollusca, gastropoda, cerithioidea) of the Albertine Rift Valley (Uganda-Congo) and their bearing on the origin and evolution of the Tanganyikan thalassoid malacofauna, Hydrobiologia, 498, 1-83, doi:10.1023/a:1026298512117, 2003.

Verbeeck, R. M. H., Driessens, F. C. M., Borggreven, J. M. P. M., and Wöltgens, J. H. M.: Concentration gradients of some minor components in human tooth enamel, B. Soc. Chim. Belg., 94, 237-243, doi:10.1002/bscb.19850940402, 1985.

Weatherell, J. A., Robinson, C., and Hallsworth, A. S.: Variations in the chemical composition of human enamel, J. Dent. Res., 53, 180-192, doi:10.1177/00220345740530020501, 1974.

Williams, M. A. J.: Late Pleistocene and Holocene environments in the Nile Basin, Global Planet. Change, 69, 1-15, 2009.

Wopenka, B. and Pasteris, J. D.: A mineralogical perspective on the apatite in bone, Mater. Sci. Eng.: C, 25, 131-143, 2005.

Wright, J., Schrader, H., and Holser, W. T.: Paleoredox variations in ancient oceans recorded by rare earth elements in fossil apatite, Geochim. Cosmochim. Acta, 51, 631-644, 1987.

Yu, Z., Ito, E., and Engstrom, D. R.: Water isotopic and hydrochemical evolution of a lake chain in the Northern Great Plains and its paleoclimatic implications, J. Paleolimnol., 28, 207-217, doi:10.1023/a:1021651824885, 2002.

Zazzo, A., Balasse, M., and Patterson, W. P.: High-resolution $\delta^{13} \mathrm{C}$ intratooth profiles in bovine enamel: Implications for mineralization pattern and isotopic attenuation, Geochim. Cosmochim. Acta, 69, 3631-3642, 2005. 